\title{
Cloning and Characterization of Aplysia Neutral Endopeptidase, a Metallo-Endopeptidase Involved in the Extracellular Metabolism of Neuropeptides in Aplysia californica
}

\author{
Jacques P. Zappulla, ${ }^{1}$ Louise Wickham, ${ }^{1}$ Wafa Bawab, ${ }^{1}$ Xiao-Feng Yang, ${ }^{1}$ Maksim V. Storozhuk, ${ }^{2}$ \\ Vincent F. Castellucci, ${ }^{2,3}$ and Luc DesGroseillers ${ }^{1,3}$ \\ ${ }^{1}$ Département de Biochimie, '2Département de Physiologie, and ${ }^{3}$ Centre de Recherches en Sciences Neurologiques, \\ Université de Montréal, Montréal, Québec, Canada, H3C 3J7
}

\begin{abstract}
Cell surface metallo-endopeptidases play important roles in cell communication by controlling the levels of bioactive peptides around peptide receptors. To understand the relative relevance of these enzymes in the CNS, we characterized a metalloendopeptidase in the CNS of Aplysia californica, whose peptidergic pathways are well described at the molecular, cellular, and physiological levels. The membrane-bound activity cleaved Leu-enkephalin at the Gly ${ }^{3}-\mathrm{Phe}^{4}$ bond with an inhibitor profile similar to that of the mammalian neutral endopeptidase (NEP). This functional homology was supported by the molecular cloning of cDNAs from the CNS, which demonstrated that the Aplysia and mammalian NEPs share all the same amino acids that are essential for the enzymatic activity. The protein is recognized both by specific anti-Aplysia NEP (apNEP) antibodies and by the [ $\left.{ }^{125} \mathrm{l}\right]$-labeled NEP-specific inhibitor RB104, demonstrating that the apNEP gene codes for the RB104binding protein. In situ hybridization experiments on sections of
\end{abstract}

Specific behaviors and various physiological functions from yeast to mammals are controlled by a wide range of bioactive peptide hormones. The use of peptides as messengers usually involves the following steps: production and release of the peptide by a specific cell, interaction of the peptide with a receptor on the surface of the target cell, and degradation of the peptide to terminate its action. The first and last steps of this scheme require the participation of proteases/peptidases. It is now acknowledged that a small number of membrane peptidases, with a broad range of specificity, act together to put an end to the biological actions of neuropeptides (McKelvy and Blumberg, 1986; Maroux, 1987; Turner, 1986; Turner et al., 1987). Most of these neuropeptidases

Received Nov. 10, 1998; revised March 8, 1999; accepted March 19, 1999.

This work was supported by grants from the Medical Research Council of Canada (MRC) and Fonds pour la Formation de Chercheurs et l'Aide á la Recherche (FCAR) to L.D.G. and V.F.C. We thank Jeanne Lavoie and Mireille Fyfe for excellent technical support, as well as Manon Moreau and Gaston Lambert for expert photographic work. We thank Dr. Philippe Crine for providing us with purified rabbit NEP, Dr. Richard H. Scheller for the generous gift of the Aplysia genomic library, and Dr. Bernard P. Roques for generously providing RB104, HACBO-Gly, and thiorphan. We also thank Dr. Hervé Le Moual for critical reading of this manuscript.

Correspondence should be addressed to Dr. Luc DesGroseillers, Département de Biochimie, Université de Montréal, C.P. 6128, Succursale Centre-Ville, Montréal, Québec, Canada H3C 3J7.

Dr. Yang's present address: Department of Cancer Immunology and AIDS, Dana-Farber Institute, Harvard Medical School, Boston, MA 02115.

Dr. Storozhuk's present address: Bogomoletz Institute of Physiology, Kiev, Ukraine.

Copyright (C) 1999 Society for Neuroscience $\quad 0270-6474 / 99 / 194280-13 \$ 05.00 / 0$ the ganglia of the CNS revealed that apNEP is expressed in neurons and that the mRNA is present both in the cell bodies and in neurites that travel along the neuropil and peripheral nerves. When incubated in the presence of a specific NEP inhibitor, many neurons of the buccal ganglion showed a greatly prolonged physiological response to stimulation, suggesting that NEP-like metallo-endopeptidases may play a critical role in the regulation of the feeding behavior in Aplysia. One of the putative targets of apNEP in this behavior is the small cardioactive peptide, as suggested by RP-HPLC experiments. More generally, the presence of apNEP in the CNS and periphery may indicate that it could play a major role in the modulation of synaptic transmission in Aplysia and in the metabolism of neuropeptides close to their point of release.

Key words: Aplysia; neutral endopeptidase; CNS; neuropeptide degradation; buccal ganglion; SCP

are zinc integral membrane proteins with their active site facing the exoplasmic side of the cell (Maroux, 1987). One of the best known of these peptidases is probably neutral endopeptidase24.11 (NEP, enkephalinase, neprilysin, CALLA), which has been implicated in the physiological degradation of several bioactive peptides (for review, see Kenny, 1993; Roques et al., 1993).

To study the importance of neuropeptide-degrading enzymes in the CNS, we used the marine snail Aplysia californica. This animal has been used extensively to study a wide range of behaviors and physiological functions. The simplicity and accessibility of its neuronal components contributed to link cellular, biochemical, molecular, and physiological studies and to finely characterize peptidergic pathways (Miller et al., 1993a,b; Brezina et al., 1995; Byrne and Kandel, 1996).

So far, three peptidase activities have been characterized and linked to the extracellular metabolism of peptides in Aplysia. A leucine aminopeptidase activity (Squire et al., 1991), an aminopeptidase $\mathrm{N}$ activity (Bawab et al., 1992), and a neutral endopeptidase activity (Bawab et al., 1993). In mammals, NEP is a cell surface metallo-endopeptidase ubiquitously distributed in the CNS and the peripheral organs (Roques et al., 1993). Previous studies demonstrated that NEP plays a critical role in atrial natriuretic factor-mediated hypotension and diuresis (Gros et al., 1989, 1990; Seymour et al., 1995; Thompson and Morice, 1996), enkephalin-mediated analgesia (Roques et al., 1980), tachykininmediated modulation of synaptic transmission (Barnes et al., 1993; Saleh et al., 1996), endothelin-mediated vasoconstriction 
(Vijayaraghavan et al., 1990), and peptide-mediated inflammatory responses (for review, see Connelly et al., 1985; Martins et al., 1990; Shipp et al., 1990, 1991; for review, see Kenny, 1993; Roques et al., 1993).

In a previous study, we identified and characterized a neutral endopeptidase activity in the kidney membranes of $A$. californica (Bawab et al., 1993). As a means to better define the physiological role of apNEP in Aplysia, we have characterized a NEP-like activity in the CNS and cloned the corresponding cDNA. We have characterized apNEP by Western blotting and apNEP mRNA in the CNS by in situ hybridization. We have also demonstrated that inhibitors of the NEP-like activity potentiate the action of endogenous neuropeptides in the buccal ganglion, and in particular of small cardioactive peptide (SCP). All together these results support the importance of peptidases in the modulation of synaptic transmission and will further our investigation into the role of the extracellular regulation of neuropeptides in behavior.

\section{MATERIALS AND METHODS}

Peptides, chemicals, and solutions. Peptides Tyr-Gly-Gly and [Leu]enkephalin were purchased from IAF Biochem International (Montréal, Quebec, Canada), L-tyrosine was from Life Technologies-BRL (Burlington, Ontario, Canada), and amastatin, 1-10 phenanthroline, phosphoramidon, phenylmethyl-sulfonyl fluoride (PMSF), and 1-O- $n$-octyl-B-Dglucopyranoside (octylglucoside) were from Sigma (St. Louis, MO). Captopril was obtained from Squibb (Princeton, NJ). Thiorphan, (3hydroxyamino-carbonyl-2-benzyl-1-oxopropyl)-glycine (HACBO-Gly) and 2[(3-iodo-hydroxy)phenylmethyl]-4- $N$-[3-(hydroxyamino-3-oxo-1phenylmethyl)propyl]amino-4-oxobutanoic acid (RB104) were obtained from Bernard P. Roques (Université René Descartes, Paris, France). The labeled substrate (tyrosyl-3,5- $\left.{ }^{3} \mathrm{H}\right)[\mathrm{Leu}]$ enkephalin was obtained from New England Nuclear (Boston, MA). [ $\left.{ }^{125} \mathrm{I}\right] \mathrm{Na}$ was purchased from Amersham (Ontario, Canada). Phosphoramidon (Sigma) was added directly to a static bath ( $2 \mathrm{ml}$ volume $)$ to obtain a final desired concentration. Artificial seawater (ASW) contained (in mM): $\mathrm{NaCl} 460, \mathrm{KCl} 10$, $\mathrm{CaCl}_{2} 11, \mathrm{MgCl}_{2} 55$, and HEPES buffer 10, $\mathrm{pH}$ 7.6.

Animals and preparations. A. californica (200-250 gm) were purchased from Marine Specimen Unlimited (Pacific Palisades, CA) or from the Aplysia Resource Facility (Miami, FL). They were maintained in a large 9001 tank at $15^{\circ} \mathrm{C}$. All physiological experiments were performed at room temperature $\left(22^{\circ} \mathrm{C}\right)$ on isolated buccal ganglia. Before dissection, the mollusks were anesthetized with an injection of an isotonic $\mathrm{MgCl}_{2}$ solution $(385 \mathrm{~mm})$ corresponding to approximately one-third of their volume. Dissection of the buccal ganglion was performed in an extracellular medium made from equal volumes of isotonic $\mathrm{MgCl}_{2}$ and ASW. The ganglia were pinned to the bottom of a Sylgard-coated chamber (3 $\mathrm{ml}$ volume) filled with $2 \mathrm{ml}$ of ASW. Both branches of the radula nerve were aspirated into a suction electrode for electrical stimulation. All preparations were rested under constant superfusion of ASW for at least 90 min before the start of an experiment.

Enzyme assays and metabolite analysis. A. californica plasma membranes were prepared as described (Bawab et al., 1992). For the enkephalindegrading activity, $5-8 \mu \mathrm{g}$ membrane proteins were preincubated for 15 min at $25^{\circ} \mathrm{C}$ in $100 \mu \mathrm{l}$ of $50 \mathrm{~mm} 2$ - $(N$-morpholino)ethanesulfonic acid (MES), $\mathrm{pH} 6.5$, in the presence of amastatin, at a concentration of $10 \mu \mathrm{M}$, alone or combined with different peptidase inhibitors. The labeled substrate $\left[{ }^{3} \mathrm{H}\right][\mathrm{Leu}]$ enkephalin $\left[\left(\right.\right.$ tyrosyl-3,5- $\left.{ }^{3} \mathrm{H}\right)$ leu-enkephalin] $(30-40 \mathrm{Ci} /$ $\mathrm{mmol}$ ) was added, and the metabolites were separated from the substrate by RP-HPLC as described previously (Bawab et al., 1993). For the $\mathrm{SCP}_{\mathrm{B}}$-degrading activity, $50 \mu \mathrm{g}$ membrane proteins were preincubated for $15 \mathrm{~min}$ at $25^{\circ} \mathrm{C}$ in $100 \mu \mathrm{l}$ of $50 \mathrm{mM} \mathrm{MES}, \mathrm{pH}$ 6.5, in the presence of $10 \mu \mathrm{M}$ amastatin and $1 \mu \mathrm{M}$ captopril. The substrate $\operatorname{SCP}_{\mathrm{B}}(10 \mu \mathrm{g})$ was added and incubated for $1 \mathrm{hr}$ at $25^{\circ} \mathrm{C}$, and the metabolites were separated from the substrate by RP-HPLC on a $\mu$ Bondapak C-18 column (Waters). A linear gradient from $95 \%$ solvent $\mathrm{A}[0.1 \%$ trifluoroacetic acid (TFA) in water] $/ 5 \%$ solvent B ( $80 \%$ acetonitrile $/ 0.1 \%$ TFA) to $100 \%$ solvent B was developed for $50 \mathrm{~min}$ at a flow rate of $1 \mathrm{ml} / \mathrm{min}$.

Molecular identification of $\left[{ }^{125} I\right] R B 104$ binding proteins in Aplysia tissues. RB104 was iodinated by the chloramine T method and purified as described previously (Bawab et al., 1993). Membrane preparations from
Aplysia CNS were solubilized for $1 \mathrm{hr}$ at $4^{\circ} \mathrm{C}$ in Tris-buffered saline, $\mathrm{pH}$ 7.5 , containing $1 \%(\mathrm{w} / \mathrm{v})$ octylglucoside. The solubilized proteins were separated by electrophoresis, electroblotted to a nitrocellulose membrane, and labeled with [ $\left.{ }^{125} \mathrm{I}\right] \mathrm{RB} 104$ as described previously (Bawab et al., 1993).

Molecular cloning of the apNEP cDNA. Filter replicates of a $\lambda \mathrm{J} 1$ genomic library were hybridized at low stringency with a 760 bp HindIIIApaI fragment (nucleotides 1616-2376) isolated from the rabbit cDNA, in $6 \times$ SSC, $5 \times$ Denhardt's solution, $20 \%$ formamide, $0.5 \%$ SDS, and 100 $\mu \mathrm{g} / \mathrm{ml}$ denatured salmon sperm DNA, at $42^{\circ} \mathrm{C}$ for $16 \mathrm{hr}$. Filters were washed in $2 \times \mathrm{SSC}, 0.1 \% \mathrm{SDS}$ at $42^{\circ} \mathrm{C}$ for $1 \mathrm{hr}$. Restriction fragments of the genomic DNA were subcloned into pUC19 and sequenced. To clone the corresponding cDNA, a $\left[{ }^{32} \mathrm{P}\right]$-labeled 68 bp genomic exon was used to screen random-primed $\lambda \mathrm{GT} 10 \mathrm{CNS}$ and ovotestis cDNA libraries. Filters were hybridized at $42^{\circ} \mathrm{C}$ for $16 \mathrm{hr}$ in $6 \times \mathrm{SSC}, 5 \times$ Denhardt's solution, $0.5 \%$ SDS, $50 \%$ formamide, and $100 \mu \mathrm{g} / \mathrm{ml}$ denatured salmon sperm DNA. After hybridization, filters were washed in $0.1 \times$ SSC, $0.1 \%$ SDS at $55^{\circ} \mathrm{C}$ for $1 \mathrm{hr}$ and exposed to Kodak x-ray film at $-80^{\circ} \mathrm{C}$. Positive clones were identified, purified, and subcloned into pBluescript (Stratagene, La Jolla, CA). Double-stranded DNA was sequenced by the dideoxynucleotide method (Sanger et al., 1977) according to Sequenase protocols (United States Biochemical Corp.). The $5^{\prime}$ end of the cDNA was cloned by $5^{\prime}$-RACE (rapid amplification of $5^{\prime}$ cDNA extremities) using Aplysia CNS poly $\left(\mathrm{A}^{+}\right)$RNA as described by Chen (1996). The first-strand cDNA was synthesized with SuperScript reverse transcriptase (Life Technologies, Burlington, ON) using a specific primer CTTGACGATCCACTTTTTCCCC (nucleotides 639-660). An oligo (dA) anchor was added to the $3^{\prime}$ end of the first strand cDNA with terminal deoxynucleotidyltransferase. A short 12-cycle round of PCR was performed as described by Chen (1996) with the same specific $3^{\prime}$ primer and the $5^{\prime}$ anchor primer TGAGGTGGTTGCCACAGGAGG $(\mathrm{T})_{20}$. The product of this PCR reaction was subjected to a second amplification using a nested, specific $3^{\prime}$ primer TCAAGGCTGCTGAGTCTTTGGG (nucleotides 601-622) and the $5^{\prime}$ anchor primer TGAGGTGGTTGCCACAGGAGG. The product was subcloned into the pCR II plasmid (Invitrogen, Carlsbad, CA) and sequenced.

$c R N A$ probes. cRNA probes of 930 bp were obtained by in vitro transcription of the HindIII-EcoRI fragment of the apNEP cDNA, subcloned in pBluescript. Probes were labeled with digoxigenin-UTP (Boehringer Mannheim, Laval, Quebec, Canada) using T7 or T3 RNA polymerase (Pharmacia Biotechnology, Baie d'Urfé, Quebec, Canada) according to the manufacturer's instructions. The size and amounts of labeled RNAs were evaluated by Northern blotting after separation on a formaldehyde-agarose gel. Probes were aliquoted and stored at $-80^{\circ} \mathrm{C}$ until use.

In situ hybridization. In situ hybridization was performed essentially as described in Panoskaltsis-Mortari and Bucy (1995) on either frozen or paraffin tissue sections. Sections were hybridized with $3 \mathrm{ng}$ of heatdenatured cRNA probe in $100 \mu \mathrm{l}$ of $50 \%$ deionized formamide, $2 \times \mathrm{SSC}$, $500 \mu \mathrm{g} / \mathrm{ml}$ heat-denatured herring sperm DNA, $250 \mu \mathrm{g} / \mathrm{ml}$ yeast tRNA, $10 \%$ dextran sulfate, for $16 \mathrm{hr}$ at $50^{\circ} \mathrm{C}$. After hybridization, slides were successively washed in $2 \times$ SSC for $5 \mathrm{~min}$ at room temperature, treated with RNase A ( $40 \mathrm{mg} / \mathrm{ml}$ in $500 \mathrm{~mm} \mathrm{NaCl}, 20 \mathrm{~mm}$ Tris-HCl, pH 7.5, $1 \mathrm{~mm}$ EDTA) at $37^{\circ} \mathrm{C}$ for $30 \mathrm{~min}$, washed in $2 \times \mathrm{SSC}, 50 \%$ formamide at $50^{\circ} \mathrm{C}$ for $15 \mathrm{~min}$, and in $1 \times$ and $0.5 \times \mathrm{SSC}$ at room temperature for $5 \mathrm{~min}$ each. Positive signals were detected using anti-digoxigenin antibodies (Boehringer Mannheim). Tissues were equilibrated for $1 \mathrm{~min}$ in antibody dilution buffer (100 mM Tris-HCl, $\mathrm{pH} 7.5,150 \mathrm{~mm} \mathrm{NaCl}$ ), blocked for 30 min in the same buffer containing $2 \%$ normal goat serum, and incubated at room temperature for at least $1 \mathrm{hr}$ with sheep anti-digoxigenin antibodies diluted 1:500. Sections were then washed in the antibody dilution buffer for $5 \mathrm{~min}$, transferred to the detection buffer (100 mM Tris-HCl, $\mathrm{pH} 9.5,100 \mathrm{~mm} \mathrm{NaCl}, 50 \mathrm{~mm} \mathrm{MgCl}_{2}$ ) for $10 \mathrm{~min}$, and incubated in 340 $\mu \mathrm{g} / \mathrm{ml}$ nitroblue tetrazolium $/ 175 \mu \mathrm{g} / \mathrm{ml}$ 5-bromo-4-chloro-3-indolylphosphate/4 toluidine salt (Boehringer Mannheim) in detection buffer. Staining was allowed to proceed overnight in the dark at $4^{\circ} \mathrm{C}$. The coloring reaction was stopped in $10 \mathrm{~mm}$ Tris- $\mathrm{HCl}$, pH 8.0, 1 mM EDTA. Sections were mounted in $33 \%$ glycerol, $1 \times$ PBS, and stored at $4^{\circ} \mathrm{C}$.

Antibodies and immunoblotting. Antibodies directed against apNEP were produced by injecting rabbits with a pool of bacterially expressed C-terminal (amino acid 288-453) and N-terminal (amino acids 454-761) apNEP protein fragments fused to a 6-His tag (Qiagen, Mississauga, $\mathrm{ON})$. Immunoblot analysis was performed using horseradish peroxidaseconjugated anti-rabbit IgG antibodies (Dako, Mississauga, ON) and the 
SuperSignal substrate (Pierce, Rockford, IL) as recommended by the manufacturer.

Electrophysiology. Intracellular microelectrodes were pulled from omega-dot borosilicate glass (WPI, Sarasota, FL) and filled with $2 \mathrm{M}$ KAc. Their resistances were between 10 and $20 \mathrm{M} \Omega$. The experiments were performed in current-clamp mode, and the voltage signals were amplified using Axoclamp 2B amplifiers (Axon Instruments). Neurons in the buccal ganglion were identified on the basis of the classification suggested by Fiore and Meunier (1979): these were A neurons corresponding to cells B4 and B5 of Gardner's classification (Gardner, 1971), and $\mathrm{B}$ neurons. A and B neurons and one or two other large silent neurons located near the B neurons were impaled in each experiment. The radula nerve was stimulated with a suction electrode with $3 \mathrm{msec}$ pulses; at the beginning of the experiment, the stimulus intensity was adjusted to evoke several spikes in A neurons (usually 2-3 V). Then the radula nerve was stimulated with trains of $30-50$ stimuli $(20 \mathrm{~Hz})$ to evoke several (two to three) waves of synaptic and electrotonic potentials in A and B neurons (see Fig. 9). The intertrain interval was 10 min. The evoked responses as well as the spontaneous background activity were continuously monitored during the experiment using a DASH iV (AstroMed) chart recorder $(25 \mathrm{~mm} / \mathrm{min}$ chart speed $)$.

\section{RESULTS}

\section{Evidence for a neutral endopeptidase-like activity in the Aplysia CNS}

To reveal the presence of a membrane-associated neutral endopeptidase activity in the Aplysia CNS, we incubated plasma membranes from pooled ganglia with $\left[{ }^{3} \mathrm{H}\right][$ Leu]enkephalin. Amastatin was added at a concentration of $10 \mu \mathrm{M}$ to reduce as much as possible the strong aminopeptidase $\mathrm{N}$ activity present in this tissue (Bawab et al., 1992). The resulting metabolites were analyzed by RP-HPLC (Fig. 1). As expected for a NEP-like activity, a peak that comigrated with the Tyr-Gly-Gly peptide is visible (Fig. $1 A$ ). It corresponds to the degradation of $1.6 \mathrm{pmol}$ of substrate per milligram of protein per minute. The tyrosine peak is probably generated by the residual aminopeptidase $\mathrm{N}$ activity (Bawab et al., 1992).

To characterize the nature of the [Leu]enkephalin-degrading activity, we used various peptidase inhibitors. The cation chelating agent 1-10-phenanthroline completely inhibited the hydrolysis of $\left[{ }^{3} \mathrm{H}\right][$ Leu]enkephalin (Table 1), suggesting that the activity is produced by a metallopeptidase. NEP inhibitors such as RB104 (Fig. 1B), HACBO-Gly, thiorphan, and phosphoramidon (Table 1) were shown to abolish the Tyr-Gly-Gly peak. In contrast, captopril, an inhibitor of the dipeptidylcarboxypeptidase (Fig. $1 C$ ), and PMSF, an inhibitor of serine proteases (Table 1), had no effect on the activity of our enzyme preparation. All of these results suggest that a metallopeptidase with an inhibitor profile similar to that of the NEPs found in Aplysia kidney and in mammals is present in the CNS of Aplysia.

\section{Binding of the highly specific NEP inhibitor [ ${ }^{125}$ I]RB104 to NEP-like proteins in the Aplysia CNS}

RB104 is a highly specific NEP inhibitor that was shown to detect as little as $2 \mathrm{ng}$ of rat NEP on a Western blot (Fournié-Zaluski et al., 1992). We first tested the affinity of the enkephalin-degrading enzyme in CNS plasma membranes for $\left[{ }^{125} \mathrm{I}\right] \mathrm{RB} 104$ and found that the $K_{\mathrm{D}}$ is similar to that of the rat NEP and the Aplysia kidney enzyme (Table 2) (Fournié-Zaluski et al., 1992; Bawab et al., 1993). [ ${ }^{125}$ I]RB104 was then used in inhibitor gel electrophoresis experiments. Solubilized CNS membrane proteins or purified rabbit NEP, which was used as a control, were separated by SDS-PAGE, transferred to nitrocellulose membranes, and incubated with $\left[{ }^{125} \mathrm{I}\right] \mathrm{RB} 104$. As shown in Figure 2, $\left[{ }^{125} \mathrm{I}\right] \mathrm{RB} 104$ binds to proteins of 100 and $200 \mathrm{kDa}$ in the Aplysia CNS membranes and to the $94 \mathrm{kDa}$ rabbit protein; this binding was com-

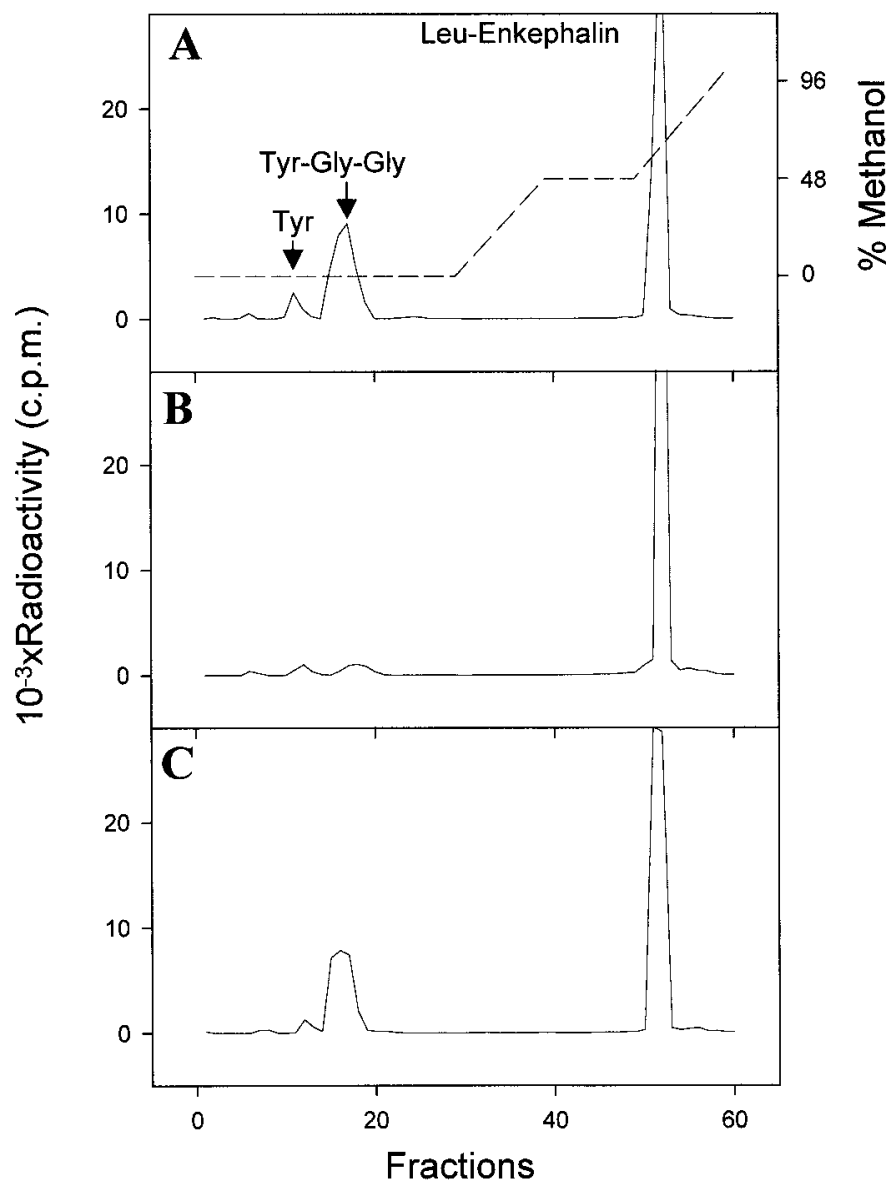

Figure 1. RP-HPLC analysis of degradation metabolites of $\left[{ }^{3} \mathrm{H}\right][\mathrm{Leu}] \mathrm{en}-$ kephalin in the Aplysia CNS. The substrate was incubated with CNS plasma membranes, in the absence $(A)$ or presence of $1 \mu \mathrm{M} \mathrm{RB104}(B)$ or $1 \mu \mathrm{M}$ captopril $(C)$. Arrows indicate the elution position of standard peptides. The dashed line represents the methanol gradient used in the HPLC.

\begin{tabular}{lccc}
\hline $\begin{array}{l}\text { Table 1. Comparison of the action of peptidase inhibitors on apNEP } \\
\text { activity present in }\end{array}$ & $\begin{array}{l}\text { Aplysia californica } \\
\text { CNS and kidney membranes }\end{array}$ \\
& $\begin{array}{l}\text { Concentration } \\
(\mu \mathrm{M})\end{array}$ & $\begin{array}{l}\text { (nead ganglia } \\
\text { membranes) }\end{array}$ & $\begin{array}{l}\text { \% Inhibition } \\
\text { (kidney } \\
\text { membranes) }\end{array}$ \\
Inhibitors & 1 & 87 & 91 \\
\hline RB104 & 10 & 91 & 74 \\
HACBO-Gly & 10 & 41 & 33 \\
Thiorphan & 10 & 41 & 45 \\
Phosphoramidon & 5 & 100 & 100 \\
1-10 Phenantroline & 10 & 11 & 0 \\
Captopril & 100 & 0 & 0 \\
PMSF &
\end{tabular}

Plasma membranes from head ganglia or kidney [results from Bawab et al. (1993)] were incubated, before the addition of the $\left[{ }^{3} \mathrm{H}\right] \mathrm{Leu}-\mathrm{enkephalin}$, in the absence or presence of various peptidase inhibitors. The enzymatic assays were performed as indicated in Materials and Methods. Results are expressed as a percentage of inhibition of substrate degradation. The percentage inhibition was calculated by comparing the radioactivity under the Tyr-Gly-Gly peak in the presence and absence of inhibitors.

${ }^{a}$ Bawab et al. (1993).

pletely abolished by NEP inhibitors such as HACBO-Gly $(10 \mu \mathrm{M})$ and phosphoramidon $(10 \mu \mathrm{M})$. In contrast, the labeling was not affected by specific inhibitors of other peptidases such as captopril $(10 \mu \mathrm{M})$ or amastatin $(10 \mu \mathrm{M})$. These results demonstrate that 


\begin{tabular}{|c|c|c|}
\hline Characteristics & CNS & Kidney $^{a}$ \\
\hline Activity $^{b}$ & $1.6 \mathrm{pmol} / \mathrm{mg}$ protein per minute & $3.5 \mathrm{pmol} / \mathrm{mg}$ protein per minute \\
\hline $\mathrm{RB} 104-K_{\mathrm{D}}{ }^{c}$ & $0.16 \times 10^{-10}$ & $0.26 \times 10^{-10}$ \\
\hline $\mathrm{RB} 104-B_{\max }^{e}$ & $12 \mathrm{fmol} / \mathrm{mg}$ protein & $20 \mathrm{fmol} / \mathrm{mg}$ protein \\
\hline \multicolumn{3}{|l|}{ RB104-inhibitor gel } \\
\hline electrophoresis (M.W.) & 100 and $200 \mathrm{kDa}$ & $140 \mathrm{kDa}$ \\
\hline Western blot (M.W. $)^{d}$ & 100 and $200 \mathrm{kDa}$ & $140 \mathrm{kDa}$ \\
\hline Northern blot ${ }^{e}$ & $+^{f}$ & ++ \\
\hline
\end{tabular}

${ }^{a}$ Bawab et al. (1993).

${ }^{b}$ Membrane preperations were incubated with [ $\left.{ }^{3} \mathrm{H}\right][\mathrm{Leu}]$ enkephalin, in the presence of amastatin at a concentration of 10 $\mu \mathrm{M}$. The metabolites were separated by RP-HPLC, and the number of counts per minute under the Tyr-Gly-Gly peak were measured as described in Bawab et al. (1993).

${ }^{c}$ Kidney plasma membranes were incubated in the presence of $\left[{ }^{125} \mathrm{I}\right] \mathrm{RB} 104$ and different dilutions of cold I-RB104. The $K_{\mathrm{D}}$ and $B_{\max }$ values were calculated from Scatchard analysis as reported previously (Bawab et al., 1993).

${ }^{d}$ Western blot realized with specific apNEP antibodies.

${ }^{e}$ Northern blot realized with an apNEP cDNA probe.

${ }^{f}$ Intensity of the hybridization signal.

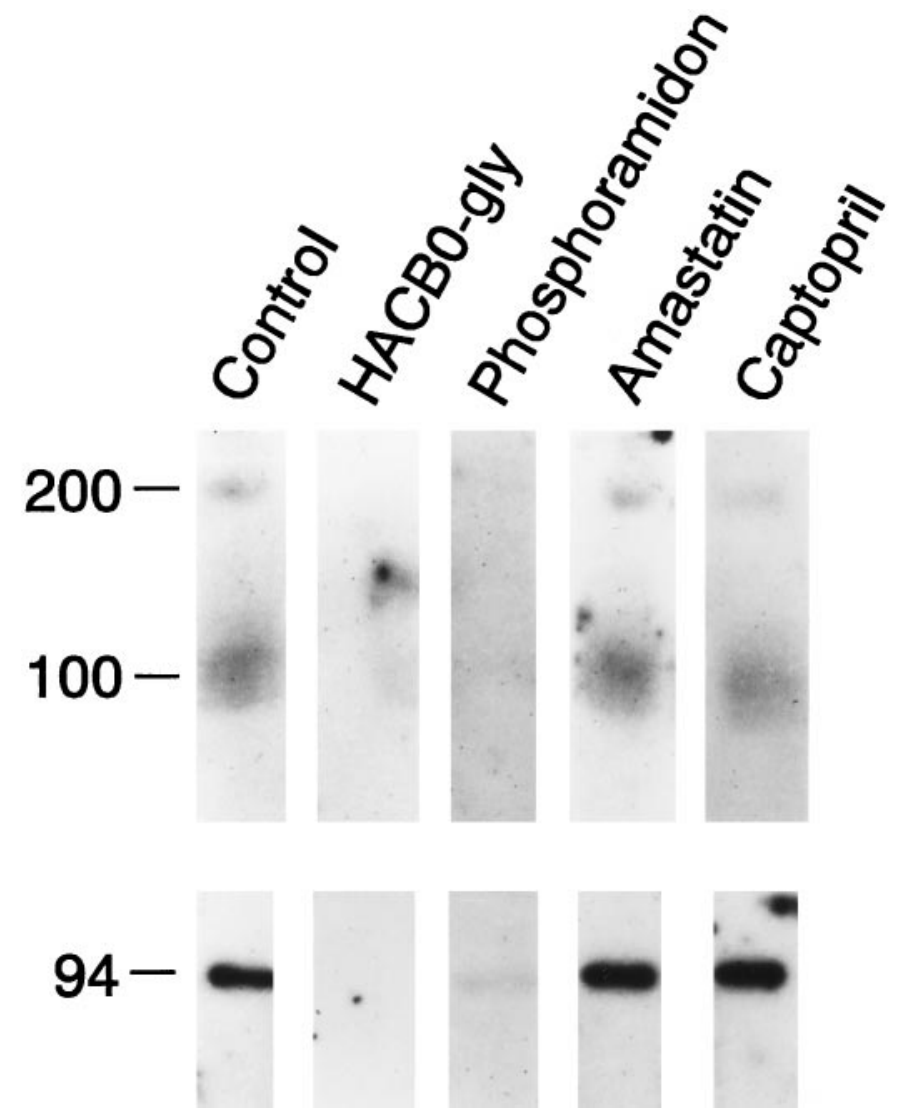

Figure 2. Inhibitor gel electrophoresis with $\left[{ }^{125} \mathrm{I}\right] \mathrm{RB} 104$ and different peptidase inhibitors. Solubilized Aplysia CNS membrane proteins (top panel) and purified rabbit NEP (bottom panel) were separated by SDSPAGE and transferred onto nitrocellulose membranes. NEP-like proteins were labeled with $100 \mathrm{pm}\left[{ }^{125} \mathrm{I}\right] \mathrm{RB} 104$ in the presence or absence of peptidase inhibitors: absence of inhibitor (Control); HACBO-gly at $10 \mu \mathrm{M}$; Phosphoramidon at $10 \mu \mathrm{M}$; Amastatin at $10 \mu \mathrm{M}$; Captopril at $10 \mu \mathrm{M}$.

NEP-like proteins are expressed in the CNS and that their molecular sizes are different from that of the $140 \mathrm{kDa}$ NEP-like enzyme already observed in the Aplysia kidney membranes. However, their active site is likely to be structurally and functionally similar, because they all bind $\left[{ }^{125} \mathrm{I}\right] \mathrm{RB} 104$ with high affinity.
These results raise the question of whether the NEP-like proteins in the kidney and CNS are differentially glycosylated isoforms of the same protein or whether they are expressed from two closely related NEP-like genes.

\section{Isolation of cDNA clones encoding an apNEP}

To answer this question, we cloned cDNAs coding for the NEPlike activity. We first screened an Aplysia genomic library at low stringency, using a $760 \mathrm{bp}$ rabbit NEP cDNA fragment as a probe (Devault et al., 1987). One of the 13 clones $(\lambda \mathrm{NEPg} 1)$ found was further characterized, and a $400 \mathrm{bp}$ fragment was subcloned and sequenced. A short segment of $68 \mathrm{bp}$, flanked by splicing consensus sequences, showed high sequence similarity to the rabbit NEP sequence (Fig. 3). Interestingly, the $3^{\prime}$ splicing site is identical to the one described for all of the NEP-like family members, and the $5^{\prime}$ splicing site is common to endothelin-converting enzyme (ECE), a human phosphate-regulating gene with homologies to endopeptidases on the X-chromosome (PHEX) and kell blood group protein (KELL) but not to NEP (Fig. 3). Considering the high level of conservation of exon/intron boundaries, these results not only suggest that apNEP is a member of the NEP family, but also indicate that the apNEP and mammalian NEP-like enzymes are likely to be derived from a common ancestor (see also below).

This 68 bp segment was PCR-amplified, subcloned, and used as a probe to screen Aplysia CNS and ovotestis cDNA libraries by plaque hybridization. Of eight positive recombinant phages, the inserts of the $\lambda 5.1, \lambda \mathrm{NEPc}, \lambda \mathrm{NEPe}$, and $\lambda \mathrm{NEPf}$ clones were sequenced. Their sequences indicated that they represented overlapping cDNAs derived from the same apNEP mRNA but that the $5^{\prime}$ region of the coding region was missing. Because we did not succeed in cloning the $5^{\prime}$ part of the cDNA by rescreening the libraries, we performed a $5^{\prime}$-RACE protocol using a set of nested specific internal primers and mRNA isolated from the CNS. This yielded one overlapping PCR product that covered the missing coding sequence and part of the 5' UTR. The first ATG is found at position 164 and is followed by an open reading frame of 2361 nucleotides that codes for a putative apNEP protein of 787 amino acids (Fig. 4). This protein is $\sim 35 \%$ identical to human NEP.

\section{Southern blot analysis of the apNEP gene}

The cloning of one small exon of the apNEP gene suggests that it could be fragmented into many exons as observed for the mammalian homologs. To assess this point, a Southern blot of $A$. 


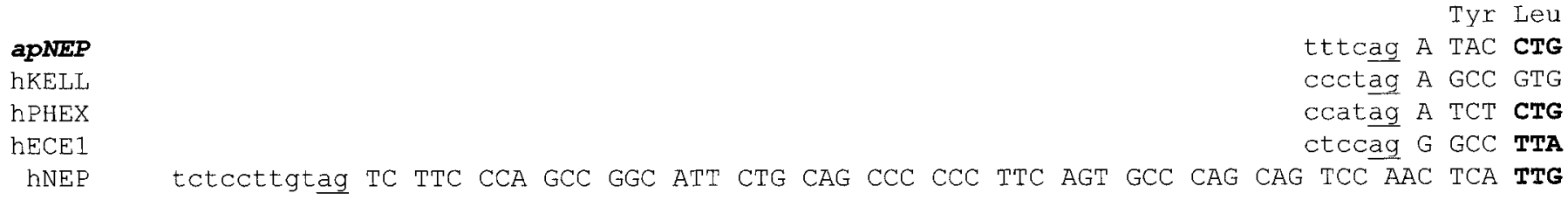

\begin{tabular}{|c|c|c|c|c|c|c|c|c|c|c|c|c|c|c|c|c|c|c|c|c|c|c|}
\hline & Asn & Tyx & Gly & Ser & Ile & Gly & $\mathrm{Val}$ & Ile & Ile & Gly & His & Glu & Ile & Thr & $\mathrm{His}$ & Gly & Phe & Asp & Asp & Lys & & \\
\hline apNEP & AAC & TAT & GGA & TCT & ATA & GGA & GTT & ATC & ATA & GGT & CAC & GAA & ATC & ACT & $\mathrm{CAC}$ & GGT & TTT & GAT & GAT & $\mathrm{AAA}$ & G & gtaa \\
\hline hKELL & $\mathrm{AAC}$ & TTT & GGC & GCT & GCT & GGC & $A G C$ & ATC & ATG & $\mathrm{CC}$ & CAC & GAG & $\mathrm{CTG}$ & TTG & $\mathrm{CAC}$ & ATC & PTC & TAC & $\mathrm{CAG}$ & CTC & $\mathrm{T}$ & gtgg \\
\hline hPHEX & $\mathrm{AGT}$ & TAT & GGT & $\mathrm{GCT}$ & ATA & GGA & GTA & ATT & GTC & A & $\mathbf{T}$ & GAA & $\mathrm{TT}$ & $\mathrm{CA}$ & $\mathrm{AT}$ & GA & 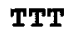 & GAT & $\triangle A T$ & $\mathrm{AT}$ & $G$ & gtag \\
\hline hECE1 & $\mathbf{A A C}$ & TTT & GGT & GGC & ATA & GGT & GTC & GTC & GTG & $\mathbf{G C}$ & CAT & GAG & $\mathrm{CTC}$ & $\mathrm{ACT}$ & CAT & GGC & TTC & GAT & GAC & AAT & $G$ & gtac \\
\hline hNEP & $A A C$ & TAT & GGG & GGC & ATC & GGC & ATG & GTC & ATA & & CAC & GAA & ATC & $\mathrm{ACC}$ & CAT & GGC & TTC & GAT & GAC & AAT & G & gtaa \\
\hline
\end{tabular}

Figure 3. Comparison of the apNEP ( $\lambda$ NEPg1 clone), hNEP, hECE1, hKELL, and hPHEX exons that code for the zinc-binding domain. Nucleotide sequences of exons and flanking introns are shown in capital and small letters, respectively. Splicing consensus sequences are underlined. The deduced amino acid sequence of the apNEP exon is shown above the nucleotide sequence. The codons for identical amino acids are in bold type, and the pentapeptide consensus sequences (His-Glu-Xaa-Xaa-His) that are part of the metalloprotease zinc-binding domain are boxed.

californica genomic DNA was digested with BglII, EcoRI, HindIII, SacI, and $X b a I$ and hybridized with a short probe. Considering the fact that no $\mathrm{SacI}$ or $B g l \mathrm{II}$ site and only one $\mathrm{XbaI}$ restriction site exists in this probe, the multiple bands that hybridized in each lane indicate that this small cDNA region corresponds to at least three exons in the genomic DNA (Fig. 5A). Consistent with the cloning of a small exon (see above), this result suggests that the genomic organization of the apNEP gene may be similar to that of the members of the NEP-like family, which are all fragmented into several exons (D'Adamio et al., 1989).

\section{Tissue expression of the apNEP mRNA, and cellular localization in the Aplysia CNS}

Northern blots of poly $\left(\mathrm{A}^{+}\right)$RNA extracted from various tissues were probed with a 316 bp apNEP cDNA fragment and used to determine the size of the apNEP transcript and its specificity of expression (Fig. 5B). A single transcript of $\sim 3.8 \mathrm{~kb}$ was abundantly present in ovotestis and kidney and very little was expressed in the CNS, gill, and heart where the signal could only be detected after a long period of exposure. By comparison with the size of the cDNA, it is likely that additional $5^{\prime}$ and/or $3^{\prime}$ untranslated sequences are present in the transcript. The presence of apNEP in these tissues was confirmed by Western blot experiments (see below). These results confirm that apNEP is expressed in both the CNS and kidney as well as in many other organs.

To determine the type(s) of cells that express apNEP in the Aplysia CNS, we performed preliminary in situ hybridization experiments on paraffined sections of the ganglia. A positive signal can be observed with a cRNA probe in many neurons of all the ganglia (Fig. 6A), demonstrating that neurons are the source of apNEP in the CNS. The signal is not restricted to the cell bodies and can also be observed in the neuropil and ganglion peripheral nerves in structures that look like neurites (Fig. 6C). The specificity of the signal was confirmed by the absence of any signal when the same experiments were performed on adjacent sections using a sense probe (Fig. $6 B$ ). At this point we did not try to identify individual neurons.

\section{Primary structure of apNEP}

The apNEP cDNA sequence encodes a putative protein of 88 $\mathrm{kDa}$, which shares important structural features with mammalian NEP. (1) As predicted by the Kyte and Doolittle (1982) hydro- phobicity plot (Fig. 7A), apNEP is a type II integral membrane protein with a short N-terminal cytoplasmic tail of 31 amino acids, a hydrophobic region of 23 residues, which represents a putative transmembrane helix, and a large extracellular C-terminal domain of 686 amino acids. (2) The extracellular portion of apNEP contains the highly conserved zinc-binding motif (residues 622-626) (Fig. 6B) and thus probably constitutes the catalytic domain. (3) apNEP contains 10 putative sites for $\mathrm{N}$-glycosylation (Asn-Xxx-Ser/Thr), suggesting that apNEP is highly glycosylated. (4) The 10 cysteine residues found in the extracellular domain of apNEP coalign with those of the mammalian NEP (Fig. 7B). (5) Nearly all of the amino acids that are essential for the enzymatic activity of the mammalian NEP (for review, see Roques et al., 1993) are found in the same position on the cDNA encoding apNEP (Table 3 ). All together, these results suggest that the apNEP cDNA codes for an Aplysia neutral endopeptidase homolog.

\section{The CNS $100 \mathrm{kDa}$ and the kidney $140 \mathrm{kDa}\left[{ }^{125} \mathrm{I}\right] \mathrm{RB} 104-$ binding proteins are likely to be coded by the apNEP gene}

To determine whether the NEP-like molecules in the CNS and kidney membranes are both expressed from the apNEP gene, immunoblots of membrane extracts from the kidney and CNS were performed, using anti-apNEP antibodies. As expected from the inhibitor gel electrophoresis experiment, a band of $140 \mathrm{kDa}$ was detected in the kidney plasma membranes, whereas a single band of $100 \mathrm{kDa}$ was detected in the membranes of the CNS (Fig. $8 A$ ). Under nonreducing electrophoresis conditions, an additional band of $\sim 200 \mathrm{kDa}$ was detected in the membranes of the CNS (Fig. 8C), suggesting strongly that the $200 \mathrm{kDa}$ protein is a dimer of the $100 \mathrm{kDa}$ protein, as observed in mammals (Kenny and Maroux, 1982). These results demonstrate the presence of apNEP in both tissues and clearly link the RB104-binding proteins in the membranes of both the CNS and kidney to the product of the apNEP gene.

The discrepancy in the apparent molecular mass of the CNS and kidney NEP-like enzymes in Aplysia membranes may be the result of post-translational modifications, such as glycosylation. To examine this point, membrane extracts from these tissues were deglycosylated with PNGase F; the resulting proteins were sepa- 
Met Ala Pro Glu Ile pro Leu Asp Ile Gln Arg Ieu Gln Phe Gln Arg Thr Thr Ser His 20 GAAACTMGGTGAAGAGCTAGAAGGACATCAGCCACGCCAGTG ATG GCC CCG GAG ATC CCA CTC GAC ATA CAA CGT TTG CAG TTT CAG AGA ACG ACA TCA CAC 222

Trp Ero Glu Glu Gin Lys Ser Lys Ala Val Trp Arg Leu Ile Ala Leu Leu Val Val Leu Val Leu Aia Leu Val Ala Ile Val Val Leu Ser 51 TGG CCA GAA GAG CAA AAG AGC AAA GCT GTC TGG CGG CTG ATT GCA CTG CIG GTG GTG CTA GTC CTT GCC CTG GTA GCT ATT GTG GTG CTT TCA 315

Ile Val Ile Val Arg Ile Arg Glu Asp Asn Lys Thr Thr Val Lys pro Glu Pro Ser Ser Gly Ser Asp Gly Thr Thr Ser Ala Ala Ser Gly 32 ATA GTC ATC GTG AGA ATC AGA GAA GAC AAC AAA ACC ACC GTC AAA CCT GAA CCT TCT TCA GGC ICA GAT GGC ACA ACA TCA GCA GCT TCA GGC 408 Ser Gly Gly Thr Thr ser Ala Ala ser Gly ser Giy Gly Thr Thr Ser Ala Asp Ser Asp Gly Lys Ile Cys Val His Glu Gly Cys Val Thr 113 TCA GGC GGC ACA ACA TCA GCA GCT TCA GGC TCA GGA GGC ACA ACA TCA GCA GAC TCA GAC GGT AAA ATT TGC GTG CAC GAG GGT TGT GTT ACG 501

Ala Ala Ala Arg Ile Met Ser Asn Leu Asp Lys Ser Val His fro Cys Asp Asn Phe Tyr Asn Phe Ala Cys Ala Asn Trp Glu Tyr Asp Arg 144 GCA GCC GCC CGC ATC ATG AGT AAC CTC GAC AAA TCA GTT CAT CCC TGT GAC AAC TTC TAC AAT TTT GCT TGI GCG AAT TGG GAA TAT GAC CGC 594

Asp Ile Pro Lys Asp Ser Ala Ala Leu Ser Val Leu Ser Glu Leu Gly Lys Lys Val Asp Arg Gin Val Lys Leu Ile Ile Glu Ala fro Ser 175 GAC ATT CCC AAA GAC TCA GCA GCC TTG AGT GTT TTA TCA GAG CTG GGG AAA AAA GTG GAT CGT CAA GTA AAA CTT ATC ATC GAA GCG CCG TCA 687

Pro pro Asp Glu Leu Pro Val Val Thr Lys Ala Lys Asn Leu Tyr Lys Ser Cys Leu Asp Leu Glu Thr Met Asp Ala Arg Gly Ile Asp Pro 206 CCA CCA GAC GAG CTG CCA GTA GTG ACG AAG GCC AAG AAT TTG TAC AAA TCC TGT CTC GAT CTA GAA ACA ATG GAT GCA CGT GGA ATC GAC CCA 780

Tyr Lys Gin Trp Leu Ser Ser Thr Ile Gly Glu Trp Pro Leu Ile Ser Ser Ala Phe Asn Glu Ser Glu Phe Asp Ile Thr Asp Ala Ile Arg 237 TAC AAG CAA TGG CTC AGT TCT ACT ATC GGA GAG TGG CCT TTG ATC TCC AGT GCT TTC AAC GAG TCG GAA TTT GAC ATC ACT GAC GCC ATC AGA 873 Lys Ala Asn Ile Tyr Gly pro Gly pro Val val Ala Phe Tyr Val Gly Thr Asp Asp Lys Asn Ser ser Lys Lys Ile Leu Lys Ile Asp Gln 268 AAA GCC AAT ATC TAC GGT CCC GGC CCC GTT GTC GCT TTC TAT GTT GGT ACT GAC GAC AAA AAC TCT TCT AAA AAG ATA CTT AAG ATA GAC CAG 966 Pro Ala Phe Gly Leu Pro Gly Gln Arg Tyr Tyr Arg Val Pro Arg Asn Asp Thr Tyr Ile tys Ala Tyr Glu Thr Tyr Leli Tyr Arg Val Ala 299 CCT GCC TTT GGT CTT CCA GGC CAG AGA TAC TAC CGA GTA CCC AGG AAC GAC ACG TAT ATC AAG GCC TAT GAG ACG TAC CTC TAC AGA GTG GCA 1059 Glu Ala Leu Gly Phe Ala Asp Pro Ala Thr Ala Giu Lys Asp Val Ala Asp Val Val Asp Phe Glu Met Gln Ile Ala Gln Ile Ser Val Arg 330 GAG GCG CTC GGA TTT GCT GAC CCC GCT ACG GCA GAG AAG GAT GTC GCG GAC GTT GTA GAT TTT GAA ATG CAG ATC GCC CAG ATT TCC GTG AGA 1152

Pro Ala Ile Arg Arg Asn Ala Asn Ala Val phe Asn pro Met Thr Leu Ala Glu Leu Asp Gln Asp phe Ser Ser Pro Glu Leu Asn Phe Ser 361 CCT GCG ATC AGA CGT AAC GCC AAT GCA GTA TTT AAC CCA ATG ACC CTG GCT GAG CTC GAC CAA GAC TTC AGT TCG CCA GAG CTC AAC TTC TCG 1245 Arg teu Ile Thr Thr Val Met Ser Ala Pro Glu Val Ala Val Ser Val Gly Asp Asp Glu Ile Ile Met Asn Arg Ser Pro Pro Tyr Phe Arg 392 AGG TTA ATC ACA ACA GTG ATG TCA GCA CCA GAA GTA GCA GTC AGT GTC GGA GAC GAT GAA ATC ATT ATG AAC AGA TCA CCC CCT TAC TTT CGG 1338 Asn Leu Thr Asp Leu Leu Arg Asn Thr Bro Lys Lys Thr Ile Ala Asn Tyr Ile Ile Trp Arg Ile Thr Ile Ser Tyr Leu Gly Thr Leu Thr 423 AAC CTT ACA GAC CTT CTT AGA AAC ACA CCA AAA AAA ACA ATA GCT AAC TAC ATC ATA TGG CGG ATT ACT ATC TCT TAC CTC GGT ACT CTG ACA 1431 Gln Val Phe Lys Asp Ile Arg Phe Glu Phe Thr Lys Ala Ile Tyr Gly Ile Glu Thr Val Gln Pro Arg Glu Leu phe Cys Thr Ser Phe Val 454 CAG GTT TTT AAA GAC ATC CGA TTT GAG TTC ACA AAG GCC ATA TAT GGT ATA GAA ACT GTT CAA CCA CGA GAG TTG TTC TGT ACA AGC TTT GTG 1524

Arg Arg Asn Val Gly phe Ile Ile Ser tys pro phe Val Asp Lys phe fhe Ser fro Glu Ala Lys Asp Val Ala Leu Glu Met Ile Ser Gly 485 AGA AGA AAT GTT GGA TTC ATC ATC AGC AAA CCG TTT GTG GAC AAG TTC TTC TCC CCA GAA GCT AAA GAT GTG GCT CTA GAA ATG ATC TCC GGT 1617 Leu Gln Ser Ala phe Asn Glu Ile Val Asp Glu Val Glu Trp Met Asp Glu Glu Thr Lys Val Val Ala Arg Glu Lys Asn Asp Ala Ile Val 516 CTI CAG TCA GCT TTT AAT GAG ATT GTA GAT GAA GTA GAA TGG ATG GAC GAA GAA ACA AAA GTA GTA GCT CGA GAA AAG AAT GAT GCA ATT GTC 1710

Ser Iys Ile Gly Tyr pro Glu phe Val Ile Asn Ser Thr Arg Ieu Thr Glu Leu Tyr Glu Asn Tyr Thr Tyr Gly Asn Asp Thr Tyr Fhe Glu 547 TCC AAG ATT GGA TAC CCC GAA TTT GTG ATC AAT TCC ACA CGA CTG ACA GAA TTG TAC GAA AAT TAC ACA TAT GGA AAT GAT ACG TAC TTC GAA 1803 Asn Ile Leu Ser tys Asn lys val Asn Val Asp Ser Ser Phe Arg Ser leu Arg Glu Leu val Asp Lys Giu Gln Trp phe Arg Ser fro Pro 578 AAC ATA TTG TCC AAG AAC AAA GTG AAT GTA GAC AGT TCT TTC CGT AGT CTG AGG GAG CTG GTG GAC AAA GAG CAA TGG TTC AGA AGT CCG CCC 1896

Thr Val Asn Ala Tyr Tyr Asn Lys Ala Gly Asn Glu Ile Val Phe Pro Ala Gly Ile Leu Gln Ser Pro Val Phe His Val Asp Phe Pro Lys 609 ACA GTT AAT GCC TAC TAT AAC AAA GCT GGC AAC GAA ATA GTG TTT CCA GCG GGA ATC TTG CAG TCA CCA GTT TTC CAT GTG GAC TTC CCG AAA 1989 Tyr Leu Asn Tyr Gly Ser Ile Gly Val Ile Ile Gly His Glu Ile Thr His Gly Rhe Asp Asp Lys Gly Arg Leu Tyr Asp Lys Asn Gly Asn 640 TAC CTG AAC TAT GGA TCT ATA GGA GTT ATC ATA GGT CAC GAA ATC ACT CAC GGT TTT GAT GAT AAA GGC AGG CTG TAT GAC AAG AAC GGA AAC 2082

Leu Asn Gln Trp Trp Ser Asn Ser Ala Ile Glu Lys the Asn Thr Gin Lys Gin Cys Ile Ile Asp Gln Tyr Gly Ala Tyr Val Met Asp Gln 671 CTG AAT CAA TGG IGG AGT AAC TCT GCT ATC GAG AAG TTT AAC ACC CAG AAG CAA TGT ATC ATT GAC CAG TAC GGA GCT TAT GTC ATG GAC CAA 2175

Val Glu Leu Asn Leu Asn Gly Ile Arg Thr Gln Gly Glu Asn Ile Ala Asp Asn Gly Val ser Lys Ser Leu Ser Gly Arg Thr Lys Leu Gly 702 GTG GAG CTC AAT CTG AAT GGA ATA CGT ACG CAG GGA GAA AAT ATT GCT GAC AAT GGC GTC TCA AAG AGT CTT TCA GGG CGT ACA AAA CTG GGT 2268

Gln Ser Thr Arg Lys Glu Glu Pro Thr Leu Pro Gly Leu Gln Tyr Thr Asn Asp Gln Leu Phe Phe Ile Ser Phe Gly Gln Thr Trp Cys Asn 733 CAA AGC ACA AGA AAA GAA GAG CCT ACC TTG CCA GGA CTT CAG TAC ACG AAC GAT CAA CTC TTT TTC ATC AGT TTT GGG CAG ACC TGG TGT AAC 2361

Met Tyr Arg Asn Asp Ala Leu Ile Ser Ser Ile Arg Ser Gly Val His Ser pro Gly Gln Tyr Arg Val Ile Gly Ser Leu Gin Asn Ser Glu 764 ATG TAC AGA AAC GAC GCT CTT ATC AGT TCC ATT CGC AGT GGC GTG CAC AGC CCG GGT CAG TAC AGA GTA ATC GGA TCT CTT CAG AAT TCT GAG 2454 Asp Phe Ala Arg Val phe Asn Cys Pro Ser Thr Ser Tyr Met Asn Ala Ala Asn Lys Cys Gln Val Trp *** GAT TTT GCC AGA GTG TrC AAC TGT CCT TCA ACA TCG TAC ATG AAC GCG GCC AAC AAA TGT CAA GTC TGG TGA ACAGGCCAATGAACTGGTCATTATTCC 2553 AGATCCGTTGATTATCGATCTGCTGTTCTTGTTTTTGTTGGTTCGTGCTTATTTTATGATGAAAGTGGAGAAAGAAAACGTTTCGITTCAAAAACAATTCGACATTCCTTTGACCAGTTGTAG 2676 ATAAATACACACTTCAAACTG $3^{\prime}$

Figure 4. Nucleotide and deduced amino acid sequence of the Aplysia neutral endopeptidase. Amino acids are numbered starting at the first ATG of the open reading frame. The putative transmembrane region is underlined. Potential sites of $N$-glycosylation are indicated by an asterisk, and the cysteine residues are bold. The zinc-binding signature HEXXH is boxed. The nucleotide sequence has been submitted to the GenBank Data Bank with accession number AF104361. 


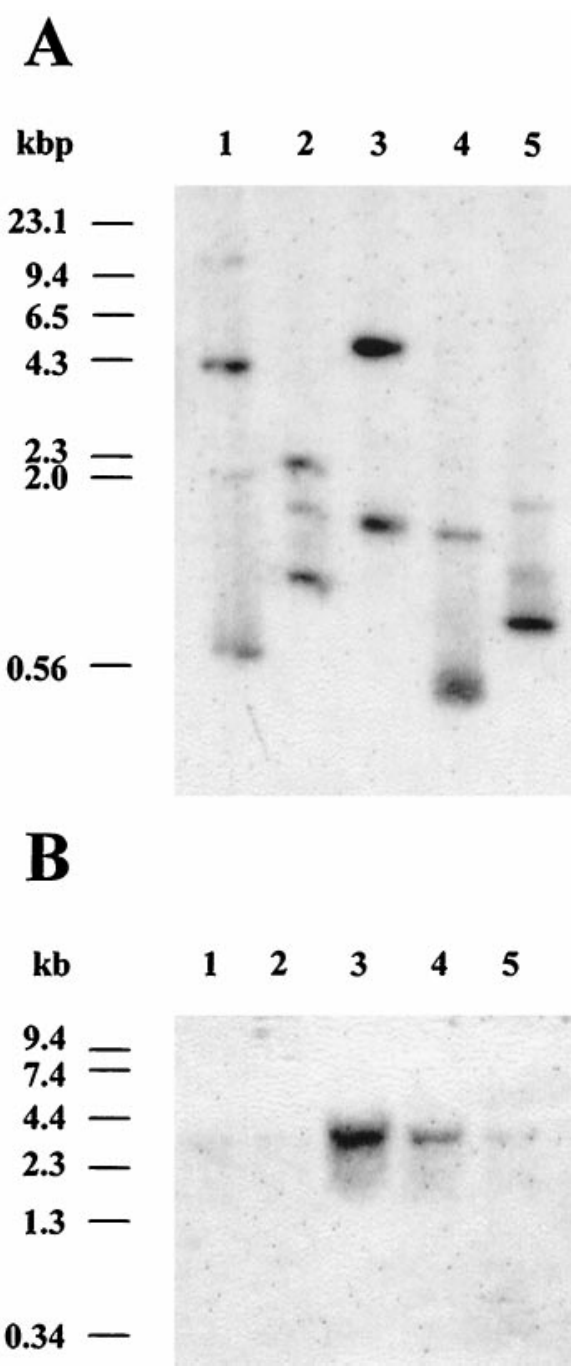

Figure 5. Southern and Northern blot analysis of the apNEP gene. $A$, Genomic DNA was isolated from ovotestis and digested with either BglII (lane 1), EcoRI (lane 2), HindIII (lane 3), SacI (lane 4), or XbaI (lane 5). Digested DNA (10 $\mu \mathrm{g} /$ lane) was run on a $0.8 \%$ agarose gel, transferred to a nitrocellulose membrane, and hybridized at high stringency with the $\left[{ }^{32} \mathrm{P}\right]$-labeled HindIII-AccI apNEP fragment (nucleotides 1142-1458) as described previously (Wickham and DesGroseillers, 1991). DNA molecular weight markers are indicated in kilobase pairs $(k b p)$ on the left. $B$, Northern blot analysis of the apNEP transcript. Total RNA was extracted from different tissues, and poly $\left(\mathrm{A}^{+}\right)$RNA $(5 \mu \mathrm{g})$ isolated from gill (lane 1), heart (lane 2), ovotestis (lane 3), kidney (lane 4), and CNS (lane 5) was fractionated on a $1 \%$ formaldehyde/agarose gel, blotted to a nitrocellulose membrane, and hybridized at high stringency with the $\left[{ }^{32} \mathrm{P}\right]-($ Hin $\mathrm{dIII}-$ AccI) apNEP fragment, as performed previously (Auclair et al., 1994). RNA molecular weight markers are indicated in kilobases $(k b)$ on the left. To control the amounts of RNA in each lane, filters were stripped and rehybridized with an Aplysia actin probe (data not shown).

rated by SDS-PAGE and detected by Western blotting. After PNGase F treatment, the molecular size of apNEP in the kidney was reduced to $\sim 88 \mathrm{kDa}$ (Fig. $8 \mathrm{~B}$ ), which is the predicted size from the cDNA sequence. This demonstrates that the $140 \mathrm{kDa}$ protein is highly glycosylated and confirms that it is probably the product of the apNEP gene. On the other hand, the size of the 100 kDa protein in the CNS (Fig. $8 B$ ), heart, and gill was unchanged. To determine whether PNGase F can remove sugars from glycoproteins expressed in the CNS membranes of Aplysia, we probed the blot with antibodies directed against 5- $\mathrm{HT}_{\text {ap1 }}$, another highly
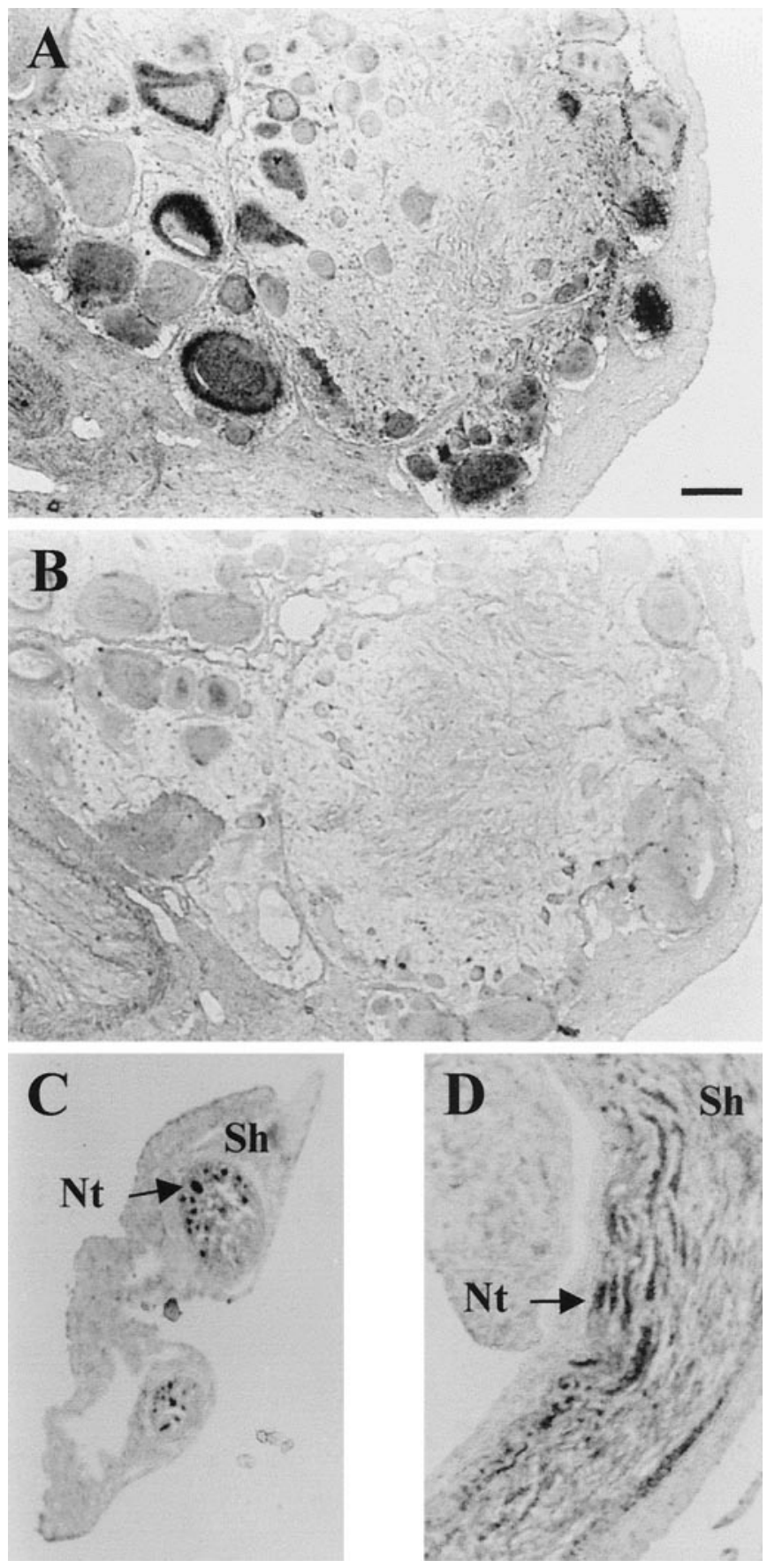

Figure 6. In situ hybridization of apNEP on paraffined sections of Aplysia ganglia. Sections of the abdominal ganglion $(A, B)$ and of a buccal ganglion nerve $(C, D)$ were hybridized with either an apNEP cRNA antisense $(A, C, D)$ or sense $(B)$ probe. Positive signal is seen in neurons $(A)$ and neurites $(N t)$ extending into the nerve. No signal is detected in the sheath $(S h)$. The same results were obtained with sections from all the major ganglia. Scale bar, $100 \mu \mathrm{m}$.

glycosylated protein (Angers et al., 1998). This protein was not deglycosylated either (data not shown), indicating that several glycosylated proteins in the CNS are PNGase F resistant.

We cloned the apNEP cDNA from the CNS in pCDNA3/RSV, and the recombinant plasmid was introduced into mammalian HEK 293 cells, as reported previously (Angers et al., 1998). Plasma membranes were purified and the protein was detected by Western blotting after PNGase F treatment. As seen in Figure 
A

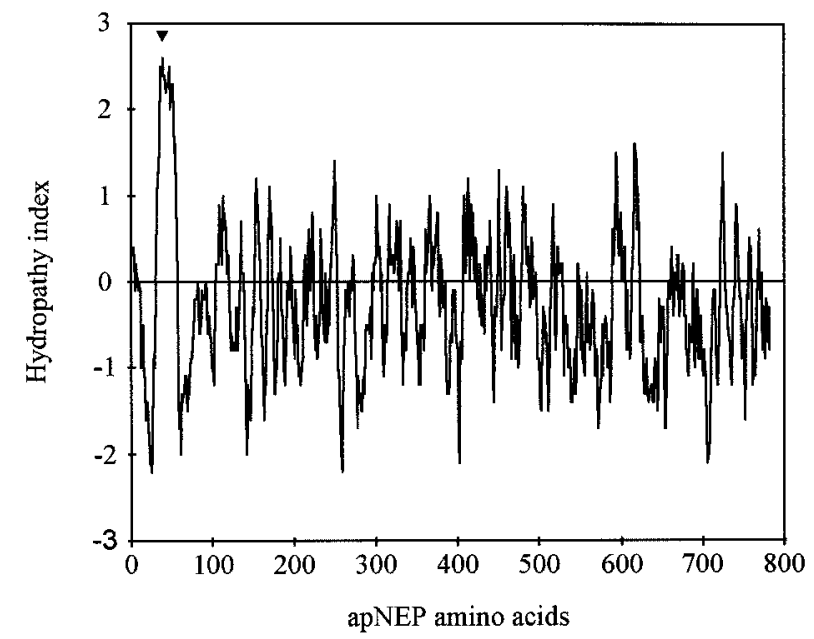

B

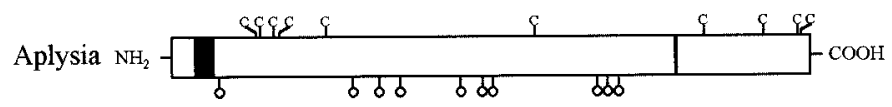

Human

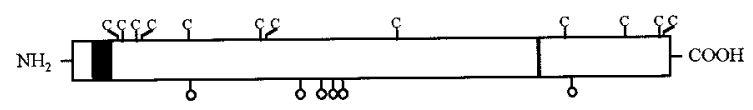

Figure 7. Molecular structure of apNEP. A, Hydropathy analysis of apNEP. The 787 amino acid-long apNEP sequence was scanned using the computer program of Kyte and Doolittle (1982). Numbers on the horizontal axis refer to the amino acid sequence. Negative values correspond to hydrophilic regions and positive values to hydrophobic regions. The arrowhead indicates the only potential membrane-spanning segment of apNEP. $B$, Schematic representation of the primary sequences of the human and Aplysia NEP proteins. The cysteine residues in the two proteins are indicated by the one-letter code $C$. The black rectangle represents the transmembrane region, and the thin rectangle represents the HEXXH gluzincin domain. The position of the possible $N$-glycosylation sites is indicated by open lollipops.

$8 B$, the results suggest that the enzyme found in Aplysia kidneys is likely to be coded by the same gene as the cDNA we isolated from the CNS because they are of the same size.

The application of a NEP-specific inhibitor potentiates the action of endogenous neuropeptides on the buccal ganglion and prevents the in vitro degradation of $\mathrm{SCP}_{\mathrm{B}}$ by Aplysia CNS membranes

In situ hybridization and Western blotting experiments (Fig. 8A) showed that apNEP is present in the buccal ganglion of Aplysia. To determine whether apNEP could be responsible for the inactivation of neuropeptides in vivo, we studied a well understood behavior in invertebrates, which is feeding. In Aplysia, feeding consists of a number of different rhythmic motor patterns, including biting, swallowing, and rejection (Kupfermann, 1974; Weiss et al., 1986). Different reports have characterized the critical roles of several neuropeptides, including $\mathrm{SCP}_{\mathrm{B}}$, FMRFamide, egg-laying hormone (ELH), buccalin, and myomodulin, as well as serotonin and acetylcholine, in the modulation of various aspects of the feeding behavior (Kreiner et al., 1987; Lloyd et al., 1987; Sossin et al., 1987; Lloyd, 1988; Miller et al., 1993a,b). Inhibition of apNEP by an apNEP-specific inhibitor should potentiate the action of secreted peptides that are normally substrates for this enzyme. Therefore, to recruit at least some of the peptidergic neurons in the ganglion, we decided to stimulate the radula nerve, because this nerve contains processes of SCP-containing neurons (Miller et al., 1994). Trains of stimuli to the radula nerve were delivered every $10 \mathrm{~min}$ (see Materials and Methods for more details); the evoked responses were recorded in A and B neurons and one or two other large cells located near the B cells. After three to four control responses, phosphoramidon $(10-100 \mu \mathrm{M})$ was added to the bath, and three to four responses were monitored in the presence of the drug; 5-10 more responses were recorded after the inhibitor was washed out. The results of an experiment, in which $10 \mu \mathrm{M}$ phosphoramidon was added, are shown in Figure 9. In the control period during the stimulation itself, there was in general a burst of action potentials and a burst of PSPs with oscillations of membrane potentials in the monitored neurons (Fig. 9A). The later parts of the evoked responses were greatly prolonged in the presence of phosphoramidon. In the example in Figure $9 A$, one can notice that the delayed firing is increased in three of the neurons. These effects were reversible after washout. The summary of five experiments (18 neurons) is shown in Figure $9 B$. These results suggest that the action of several endogenous peptides in the buccal ganglia can be enhanced because of the decrease of their degradation by a NEPlike enzyme present in this ganglion.

Because exogenous applications of $\mathrm{SCP}_{\mathrm{B}}$ induce the same physiological responses on these neurons as those obtained after radula nerve stimulation (data not shown), we tested whether $\mathrm{SCP}_{\mathrm{B}}$ is a substrate for apNEP in vitro. Using RP-HPLC, we showed that $\mathrm{SCP}_{\mathrm{B}}$ is cleaved by Aplysia $\mathrm{CNS}$ membrane extracts and that this cleavage is inhibited by the NEP inhibitor phosphoramidon $(10 \mu \mathrm{M})$. As seen in Figure 10, the peak corresponding to the uncleaved SCP peptide is clearly preserved in the presence of phosphoramidon. In the absence of the inhibitor, this peak is strongly reduced, and other peaks appeared, probably corresponding to the metabolites resulting from the degradation of $\mathrm{SCP}_{\mathrm{B}}$ by a NEP-like enzyme present in the membrane protein extract.

\section{DISCUSSION}

\section{Endopeptidase activity in the CNS}

Previous studies showed that an endopeptidase with catalytic properties similar to those of neutral endopeptidase-24.11 is present in the kidney of $A$. californica (Bawab et al., 1993). In this paper, we demonstrate that this activity also exists in the CNS of this mollusk. The HPLC profiles of [Leu]enkephalin degradation, the sensitivity of this activity to specific NEP inhibitors, and the binding of $\left[{ }^{125} \mathrm{I}\right] \mathrm{RB} 104$ to the protein all strongly suggest that the CNS and kidney endopeptidases are similar. However, the CNS endopeptidase migrates as a $100 \mathrm{kDa}$ protein band on a Western blot. Although consistent with the size of the mammalian (Kenny et al., 1987; Fournié-Zaluski et al., 1992) and the mollusk Mytilus edulis (Shipp et al., 1990) NEPs, the CNS protease is much smaller than the one found in the Aplysia kidney (Bawab et al., 1993). Our results demonstrate that not only is the pattern of glycosylation of apNEP different in the kidney and CNS, as observed in mammals (Roques et al., 1993), but the nature of the sugars that are added to the glycoproteins is likely to be different in these tissues. This could be attributable to the presence of a fucose residue on the first $N$-acetylglucosamine of the oligosaccharide chain in the CNS; this addition is known to inhibit the cleavage of sugar chains by PNGase F, and fucose residues have been reported in different glycoproteins isolated from the CNS of Aplysia (Thompson et al., 1976; Ambron et al., 1985; Goldberg 
Table 3. Comparison of the essential amino acids of thermolysin (TLN), mammalian neutral endopeptidase (mamNEP), and Aplysia californica neutral endopeptidase (apNEP)

\begin{tabular}{|c|c|c|c|c|}
\hline Action & $\mathrm{TLN}^{a}$ & mamNEP & apNEP & References \\
\hline \multicolumn{5}{|l|}{ Coordination of the zinc } \\
\hline \multirow[t]{3}{*}{ atom } & His 142 & His $583^{b}$ & His 622 & Colman et al., 1972; Hangauer et al., 1984; Devault et al., 1988; Le Moual et al., 1993 \\
\hline & His 146 & His $587^{b}$ & His 626 & Colman et al., 1972; Hangauer et al., 1984; Devault et al., 1988; Le Moual et al., 1993 \\
\hline & Glu 166 & Glu $646^{b}$ & Glu 684 & Colman et al., 1972; Le Moual et al., 1991, 1993 \\
\hline Catalysis & Glu 143 & Glu $584^{b}$ & Glu 623 & Colman et al., 1972; Weaver et al., 1977; Devault et al., 1988 \\
\hline \multirow[t]{4}{*}{ Substrate binding } & & Arg $102^{b}$ & Ala 152 & Bateman et al., 1989; Beaumont et al., 1991; Kim et al., 1992 \\
\hline & Arg 203 & Arg $717^{b}$ & Arg 755 & Colman et al., 1972; Holmes and Matthews, 1982; Marie-Claire et al., 1997 \\
\hline & Asn 112 & Asn $542^{b}$ & Asn 581 & Roderick et al., 1989; Dion et al., 1995 \\
\hline & Ala 113 & Ala 543 & Ala 582 & Weaver et al., 1977 \\
\hline \multicolumn{5}{|l|}{ Stabilization of the } \\
\hline transition state & His 231 & His $711^{b}$ & His 749 & Colman et al., 1972; Dion et al., 1993 \\
\hline & Asp 170 & Asp $650^{b}$ & Asp 688 & Colman et al., 1972; Christianson and Alexander, 1990; Le Moual et al., 1994 \\
\hline
\end{tabular}

${ }^{a}$ Determined by crystallographic studies.

${ }^{b}$ Determined by site-directed mutagenesis experiments.
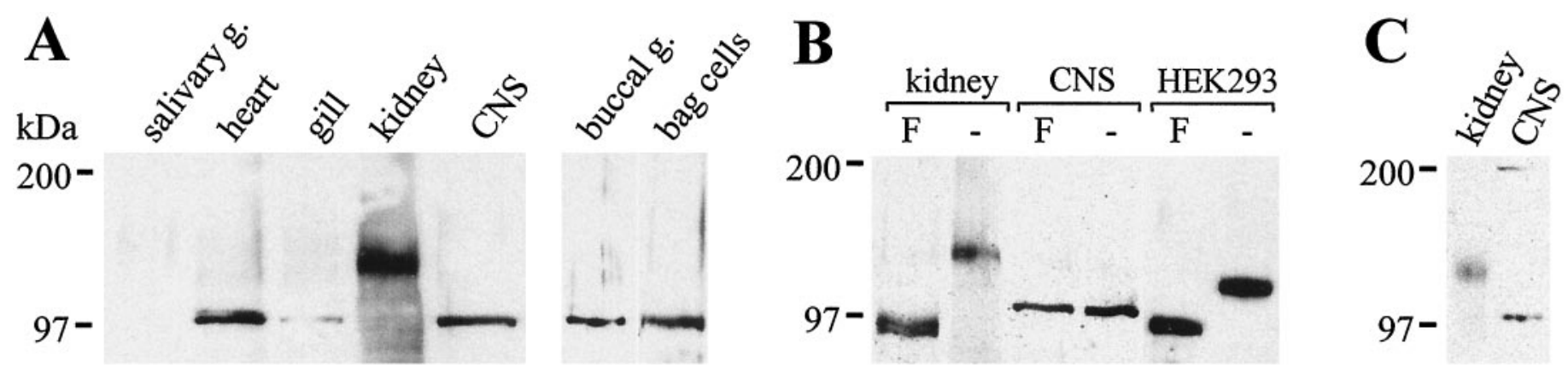

Figure 8. Immunoblot analysis of the expression and glycosylation of apNEP in different $A$. californica tissues. $A$, Twenty micrograms of solubilized membrane proteins (salivary gland, heart, gill, kidney, and CNS) and $30 \mu \mathrm{g}$ of total protein extracts (buccal ganglion and bag cells) were separated on a $6 \%$ SDS-polyacrylamide gel under reducing conditions, blotted, and detected with an anti-apNEP antisera. $B$, Plasma membrane protein extracts isolated from Aplysia tissues (kidney, CNS) or from transiently transfected mammalian HEK293 cells (HEK293) were incubated in the absence (-) or presence $(F)$ of PNGase $\mathrm{F}$, before loading on the gel. $C$, SDS-PAGE under nonreducing conditions. The arrow indicates the position of the $200 \mathrm{kDa}$ band.

and Ambron, 1986; Cleary and Schwartz, 1987). The meaning of this differential glycosylation is unknown because both proteins seem to exhibit similar [Leu]enkephalin-degradation activities, affinities for RB104 (Table 2), and responses to different NEP inhibitors (Table 1).

More significantly, our results with $\left[{ }^{125} \mathrm{I}\right] \mathrm{RB} 104$ and the antiapNEP antibodies clearly link the RB104-binding protein in the plasma membranes of both the kidney and CNS to the product of the apNEP gene. We do not yet know whether the enkephalindegrading activity in these membranes is generated by apNEP, although the binding of $\left[{ }^{125} \mathrm{I}\right] \mathrm{RB} 104$ to a single protein in both the CNS and kidney is a strong indication for the expression of a single NEP-like gene in these tissues.

\section{Structure/function of apNEP}

As described previously for the kidney endopeptidase, the activity of the CNS enzyme is low and does not allow us to fully characterize it. The molecular cloning of the apNEP cDNA represents a first step toward achieving this goal. The predicted molecular size, topological localization in the membranes, and peptidic sequence of the protein places apNEP in the large family of NEP-like enzymes (Turner and Tanzawa, 1997). Indeed, a phylogenetic analysis localizes apNEP at the branching point of mammalian NEP-like enzymes, suggesting that apNEP may be considered as the ancestor of these genes (Fig. 11). After the separation of vertebrates from invertebrates, it is likely that the ancestor NEP gene duplicated and diverged to generate peptidases involved in several physiological processes (NEP) (Roques et al., 1993), in bone and tooth mineralization processes (PHEX) (The HYP Consortium, 1995; Ruchon et al., 1998), in the control of blood pressure (ECEs) (Turner and Murphy, 1996; Webb et al., 1997), or in a still uncharacterized function in erythrocytes (KELL) (Lee et al., 1991). Consistent with this hypothesis, most of the residues that have been shown to be essential for the activity and/or conformation of human NEP are conserved at the same position in apNEP (Table 3). Such high conservation in the nature and position of all these residues is very significant when we consider that the two proteins originated from organisms whose ancestors diverged 600 million years ago, and it suggests that these residues were subjected to severe evolutionary constraints to keep the proper folding of its active site. In particular, the 10 cysteine residues in the ectodomain of apNEP and PHEX, which contribute to the stabilization of the active enzyme's conformation (Tam et al., 1985), not only align perfectly in each protein but are also conserved in NEP, ECEs, and KELL. This again suggests that the structure of apNEP is close to that of the ancestor protein and that some of the mammalian NEP-like enzymes may have evolved by acquiring extra pairs of cysteine residues. Interestingly, the cluster of four cysteines $\left(C-\mathrm{X}_{4}-\mathrm{C}-\mathrm{X}_{17^{-}}\right.$ $\left.\mathrm{C}-\mathrm{X}_{7}-\mathrm{C}\right)$, which is located a few amino acids downstream from the transmembrane domain in all members of the NEP-like 
A
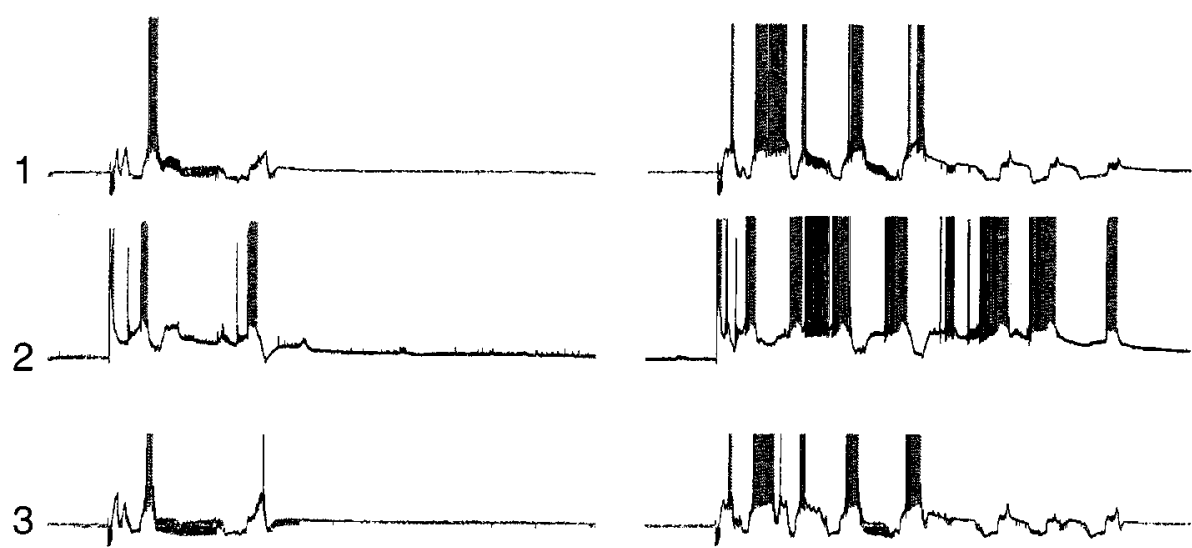

PHOSPHORAMIDON 10 $\mu \mathrm{M}$
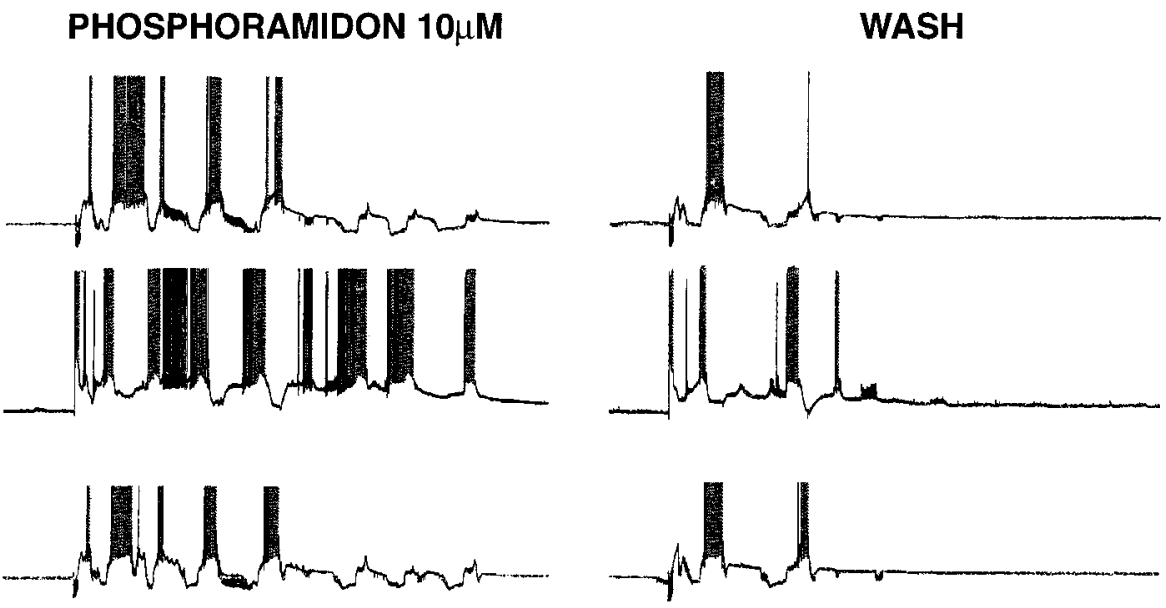

4
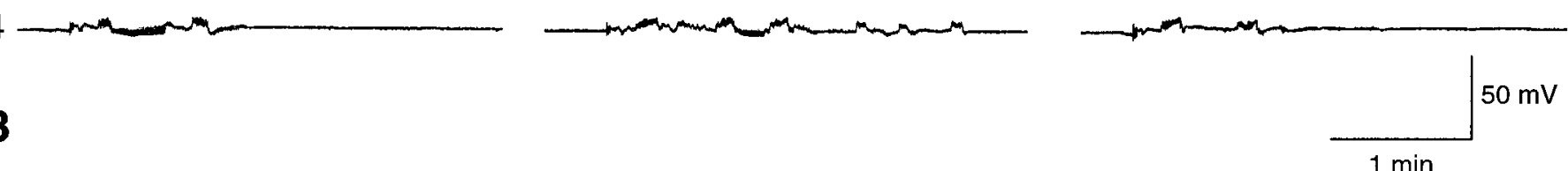

B

$1 \mathrm{~min}$

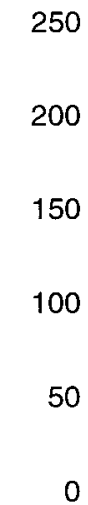

250
200
150
100
50
0

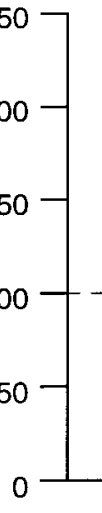

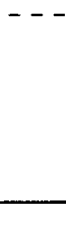
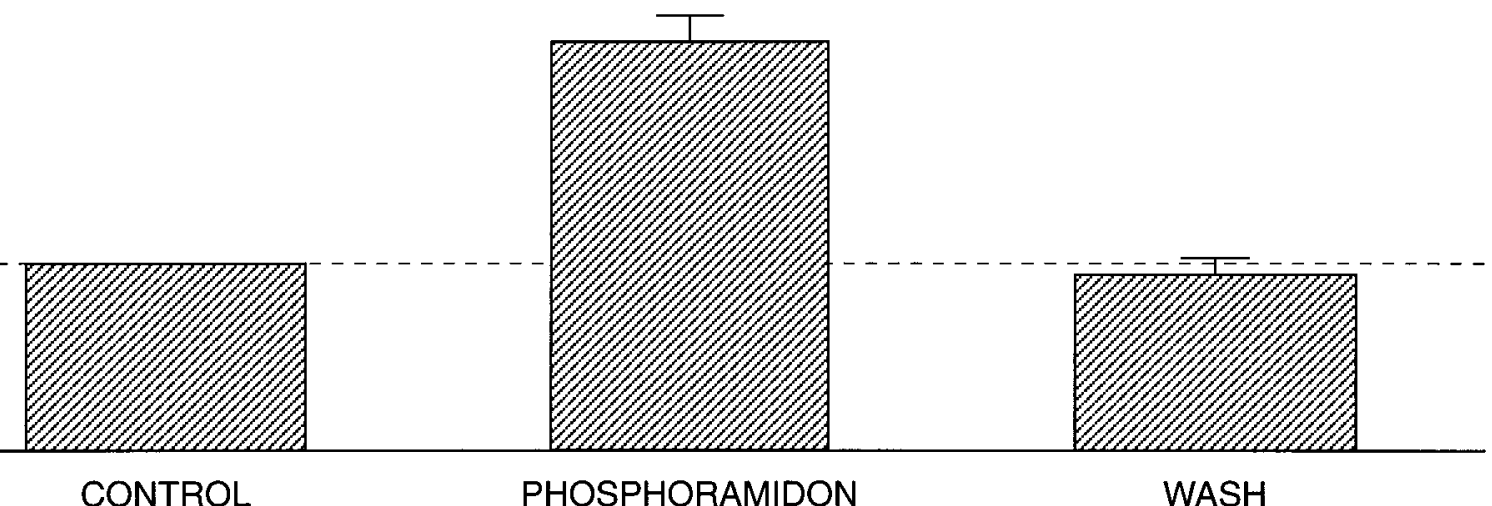

Figure 9. Phosphoramidon prolongs the responses of the buccal neurons to radula nerve stimulation. $A$, Simultaneous recordings from four neurons before, during, and after exposure to phosphoramidon $(10 \mu \mathrm{M})$. In all cases the activity evoked is prolonged: trace 1, B neuron; trace 2, A neuron; trace 3 , B neuron; trace 4, unidentified cell (see Results for details). $B$, Summary of five experiments (18 neurons) with phosphoramidon (10 or $100 \mu \mathrm{M})$. Prolongation of the responses evoked by radula nerve stimulation was observed in all the monitored neurons. The duration of the recruited activity was normalized to each respective control. The percentage average of every neuron in one experiment contributed to the average score of that experiment.

family, is separated from the transmembrane domain by a spacer of 50 amino acids in apNEP. This spacer contains many serine and threonine residues, suggesting that it may allow O-glycosylation of the protein and/or a better exposure of the active site at the cell surface. Alternatively, it may promote the cleavage of apNEP by a specific protease. Such a feature, which would either modulate the activity of apNEP at the membrane or liberate the protein into the extracellular fluid, has been described for human NEP (hNEP) (Almenoff et al., 1984; Johnson et al., 1985; Deschodt-Lanckman et al., 1989; Soleilhac et al., 1996). This may be particularly useful in Aplysia, which has an open circulatory system with arteries leading directly to open tissue spaces (Kandel, 1979). The presence of soluble peptidases in the hemocel may be a more efficient way to degrade peptides, a possibility supported by the description of metallopeptidase activities in Aplysia hemolymph (Squire et al., 1991; Bawab et al., 1992; Owens et al., 1992; Rothman et al., 1992).
$\operatorname{Arg}^{102}$ is the only functional residue that is not shared by apNEP and mammalian NEP. It is known to play a role in substrate binding and to interact with the free carboxy group of the $\mathrm{P}^{\prime} 2$ residue of some substrates (e.g., enkephalins), allowing a dipeptidyl-carboxypeptidase-like activity (Beaumont et al., 1991). The absence of this arginine in the active site of apNEP could explain the weak enzymatic activity of apNEP toward enkephalins. In addition, we demonstrated previously that the enkephalindegrading enzyme in kidney plasma membranes is a real endopeptidase because it degrades [Leu]enkephalinamide, a peptide that is protected from degradation by carboxypeptidases (Bawab et al., 1993).

\section{Physiological role of apNEP}

As observed in mammals (Roques et al., 1993), apNEP is found in many tissues, suggesting that it could be involved in the regulation of different peptidergic pathways. Indeed, neuropep- 


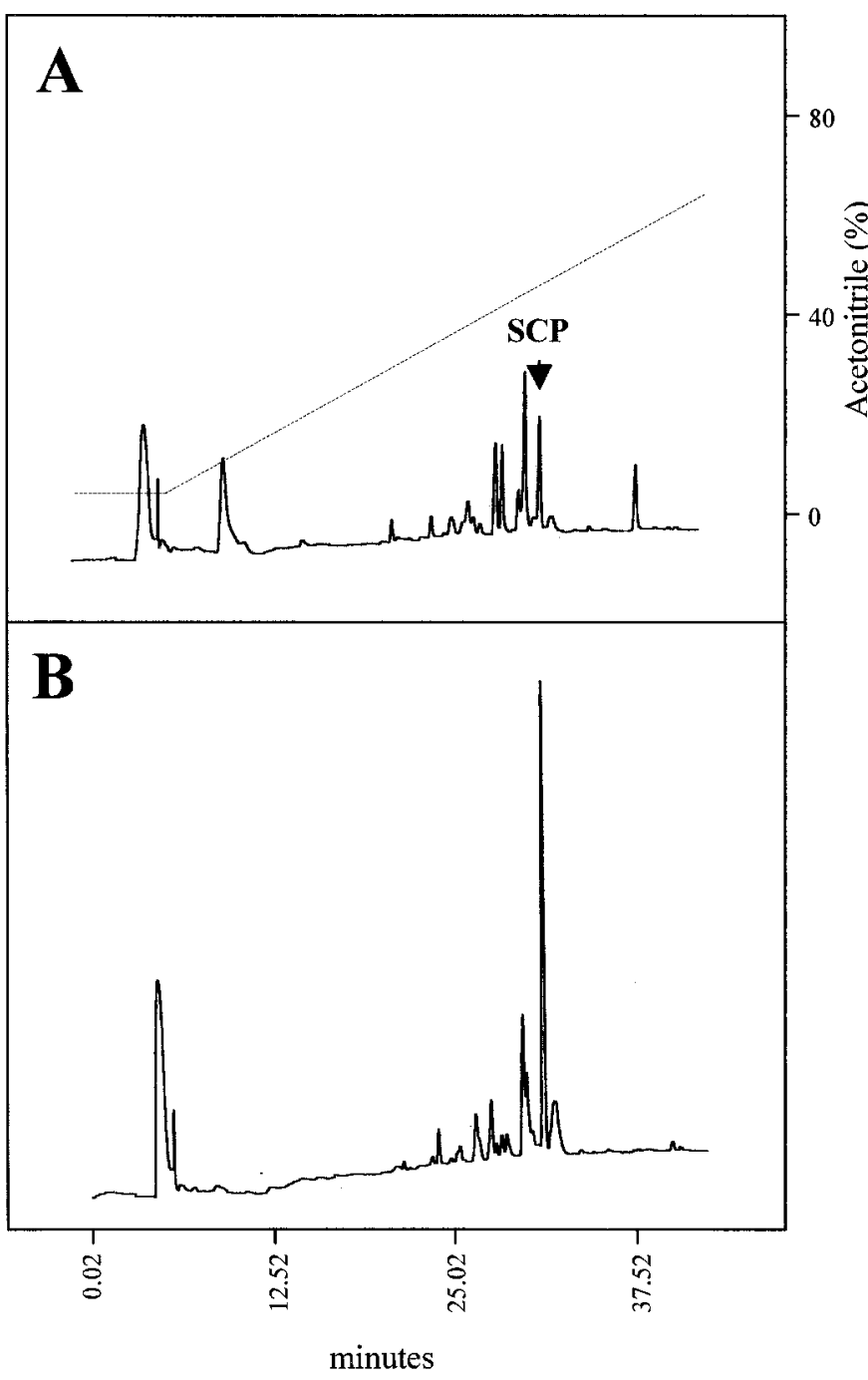

Figure 10. $\mathrm{SCP}_{\mathrm{B}}$ is degraded by an Aplysia CNS NEP-like enzyme. $\mathrm{SCP}_{\mathrm{B}}$ was incubated with CNS plasma membranes, in the absence $(A)$ or presence of $10 \mu \mathrm{M}$ phosphoramidon $(B)$. The arrow indicates the elution position of the uncleaved $\mathrm{SCP}_{\mathrm{B}}$. The dashed line represents the acetonitrile gradient used in the HPLC.

tides are ubiquitously present in Aplysia, and many of them are potential substrates for apNEP. Localization of apNEP by in situ hybridization and/or immunohistochemistry can provide important clues concerning its physiological roles and may guide the search for its physiologically relevant substrates. Colocalization of apNEP and specific peptides, and potentialization of the action of the peptides by specific enzyme inhibitors in vivo, are the two most important criteria to establish the physiological relevance of a peptidase in the regulation of a peptidergic pathway.

Our results suggest that apNEP-like peptidases in the buccal ganglion may be involved in the regulation of the feeding behavior. apNEP is expressed in this ganglion, and NEP-inhibitors potentiate the action of the peptides, most likely by controlling their rate of degradation. In this pathway, SCPs, myomodulin, and buccalin are potential substrates (Kreiner et al., 1987; Lloyd et al., 1987; Sossin et al., 1987; Miller et al., 1992). We have shown that one of these peptides, $\mathrm{SCP}_{\mathrm{B}}$, is effectively degraded by a CNS NEP-like enzyme. Similarly, in the abdominal ganglion, $\alpha$-bag cell peptide ( $\alpha$-BCP) (Owens et al., 1992), which is a

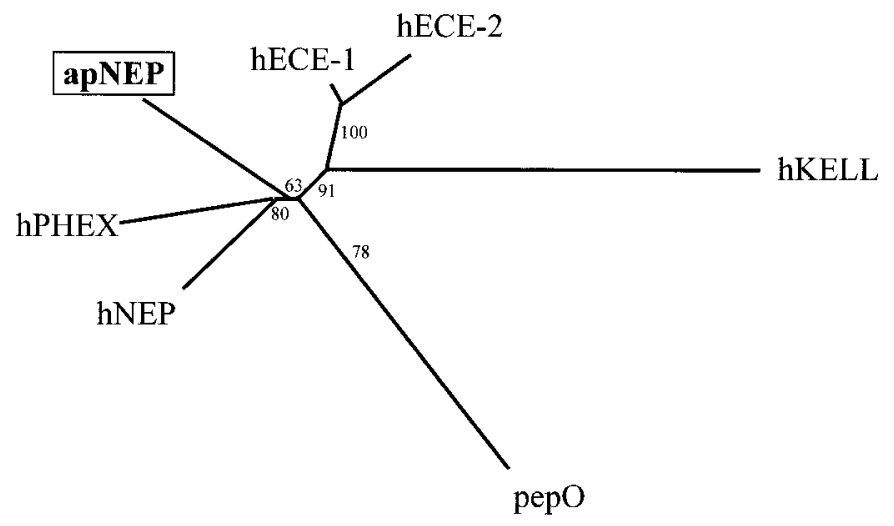

Figure 11. Phylogenetic analysis of the members of the NEP-like family. Sequences were aligned using the Clustal V program (Thompson et al., 1994). The phylogenetic tree was constructed using the Neighbor Joining method (Saitou and Nei, 1987) with a bootstrap analysis that calculates the probability of occurrence of the presented branching for 100 possible trees (Felsenstein, 1993). $h N E P$, Human neutral endopeptidase (accession number M26605); $h E C E-1$, human endothelin-converting enzyme 1 (accession number Z35307); $h E C E$-2, human endothelin-converting enzyme 2 (accession number AB011179); apNEP, A. californica neutral endopeptidase (accession number AF104361); hPHEX, human phosphateregulating gene with homologies to endopeptidases on the $X$-chromosome (accession number Y10196); $h K E L L$, human kell blood group protein (accession number M64934); pepO, lactococcus lactis PepO gene (accession number L04938). Sequences were aligned, and only the peptide regions that could be aligned with the PepO sequence were retained for the analysis; this roughly corresponds to the extracellular parts of the human and mollusk enzymes.

neuropeptide that mediates the bag cell-induced inhibition of left upper quadrant cells (LUQ) and acts together with ELH to coordinate long- and short-lasting events in the egg-laying program (Rothman et al., 1985), was reported to be rapidly degraded by endogenous peptidases when applied to the abdominal ganglion in the absence of peptidase inhibitors (Rothman et al., 1985). Analysis of the metabolites revealed that among other peptidases, a NEP-like activity is involved in $\alpha$-BCP degradation. The expression of apNEP by the LUQ cells (data not shown) and the presence of apNEP in the bag cell extracts (Fig. 7A) is consistent with the possibility that it could be involved in this $\alpha$-BCP-degrading activity.

As observed in mammals (Barnes et al., 1988; Roques et al., 1993), the apNEP gene is expressed in neurons. This suggests that the protein may be present in proximity to peptide receptors where it can play a major role in the modulation of synaptic transmission by controlling the metabolism of neuropeptides close to their site of action. The presence of apNEP mRNA in neurites that come from the ganglia via peripheral nerves suggests that a finer regulation in the level of apNEP may be exerted by local translation of the transcript in neurites. Transport and local translation of mRNAs is now well documented (Wilhelm and Vale, 1993; Steward, 1997), although the significance of this phenomenon is not completely understood. There is building evidence that local translation of mRNA in neurites serves to locally modulate the action of the translated product in response to changing physiological conditions (Van Minnen, 1994; Martin et al., 1997).

The Aplysia nervous system uses a wide variety of neuropeptides to modulate its behavior and physiological functions, and several peptidases are responsible for the regulation of the actions of these peptides. A global understanding of the function of any 
neuropeptide requires knowledge of its synthesis, release, target tissues, and regulation. The present study provides insight into the nature and distribution of the Aplysia neuropeptidase apNEP and provides the necessary tools to further investigate the role that the extracellular regulation of neuropeptides plays in behavior.

\section{REFERENCES}

Almenoff J, Teirstein AS, Thornton JC, Orlowski M (1984) Identification of a thermolysin-like metallo-endopeptidase in serum: activity in normal subjects and in patients with sarcoidosis. J Lab Clin Med 103:420-431.

Ambron RT, Schachen S, Rayport SG (1985) Proteins rapidly transported to the synapses of a single identified neuron of Aplysia californica. J Neurosci 5:2866-2873.

Angers A, Storozhuk MV, Duchaine T, Catellucci VF, DesGroseillers L (1998) Cloning and functional expression of an Aplysia 5-HT receptor negatively coupled to adenylate cyclase. J Neurosci 18:5586-5593.

Auclair D, Lang BF, Forest P, DesGroseillers L (1994) Analysis of genes encoding highly conserved lysine-rich proteins in Aplysia californica and Saccharomyces cerevisiae. Eur J Biochem 220:997-1003.

Barnes K, Turner AJ, Kenny AJ (1988) Electromicroscopic immunocytochemistry of pig brain shows that endopeptidase-24.11 is localized in neuronal membranes. Neurosci Lett 94:64-69.

Barnes K, Turner AJ, Kenny AJ (1993) An immunoelectron microscopic study of pig substantia nigra shows co-localization of endopeptidase-24.11 with substance P. Neuroscience 53:1073-1082.

Bateman Jr RC, Jackson D, Slaughter CA, Unnithan S, Chai YG, Moomaw C, Hersh LB (1989) Identification of the active-site arginine in rat neutral endopeptidase 24.11 (enkephalinase) as arginine 102 and analysis of a glutamine 102 mutant. J Biol Chem 264:6151-6157.

Bawab W, Querido E, Crine P, DesGroseillers L (1992) Identification and characterization of aminopeptidases from Aplysia californica. Biochem J 286:967-975.

Bawab W, Aloyz RS, Crine P, Roques BP, DesGroseillers L (1993) Identification and characterization of a neutral endopeptidase activity in Aplysia californica. Biochem J 296:459-465.

Beaumont A, Le Moual H, Boileau G, Crine P, Roques BP (1991) Evidence that both arginine 102 and arginine 747 are involved in substrate binding to neutral endopeptidase (EC 3.4.24.11). J Biol Chem 266:214-220.

Brezina V, Bank B, Cropper EC, Rosen C, Vilim FS, Kupfermann I (1995) Nine members of the myomodulin family of peptide cotransmitters at the B16-ARC neuromuscular junction of Aplysia. J Neurophysiol 74:54-72.

Byrne JH, Kandel ER (1996) Presynaptic facilitation revisited: state and time dependence. J Neurosci 16:425-435.

Chen Z (1996) Simple modifications to increase specificity of the 5'RACE procedure. Trends Genet 12:87-88.

Christianson DW, Alexander RS (1990) Another catalytic triad? Nature 346:225.

Cleary LJ, Schwartz JH (1987) Movement of newly synthesized membrane by fast transport along the axon of an identified Aplysia neuron. J Comp Neurol 263:92-105.

Colman PM, Jansonius JN, Matthews BW (1972) The structure of thermolysin: an electron density map at $2-3$ A resolution. J Mol Biol 70:701-724.

Connelly JC, Skidgel RA, Schulz WW, Johnson AR, Erdos EG (1985) Neutral endopeptidase 24.11 in human neutrophils: cleavage of chemotactic peptide. Proc Natl Acad Sci USA 82:8737-8741.

D’Adamio L, Shipp MA, Masteller EL, Reinherz EL (1989) Organization of the gene encoding common acute lymphoblastic leukemia antigen (neutral endopeptidase 24.11): multiple miniexons and separate 5' untranslated regions. Proc Natl Acad Sci USA 86:7103-7107.

Deschodt-Lanckman M, Michaux F, DePrez E, Abramovicz D, Vanherweghem JL, Goldman M (1989) Increased serum levels of endopeptidase 24.11 ("enkephalinase") in patients with end-stage renal failure. Life Sci 45:133-141.

Devault A, Lazure C, Nault C, Le Moual H, Seidah NG, Chretien M, Kahn P, Powell J, Mallet J, Beaumont A, Roques BP, Crine P, Boileau G (1987) Amino acid sequence of rabbit kidney neutral endopeptidase 24.11 (enkephalinase) deduced from a complementary DNA. EMBO J 6:1317-1322.

Devault A, Sales V, Nault C, Beaumont A, Roques BP, Crine P, Boileau
G (1988) Exploration of the catalytic site of endopeptidase 24.11 by site-directed mutagenesis. Histidine residues 583 and 587 are essential for catalysis. FEBS Lett 231:54-58.

Dion N, Le Moual H, Crine P, Boileau G (1993) Kinetic evidence that His-711 of neutral endopeptidase 24.11 is involved in stabilization of the transition state. FEBS Lett 318:301-304.

Dion N, Le Moual H, Fournié-Zaluski MC, Roques BP, Crine P, Boileau G (1995) Evidence that Asn542 of neprilysin (EC 3.4.24.11) is involved in binding of the $\mathrm{P} 2$ ' residue of substrates and inhibitors. Biochem J 311:623-627.

Felsenstein J (1993) PHYLIP (phylogeny inference package) 3.5.1c. Seattle, WA: University of Washington.

Fiore L, Meunier JM (1979) Synaptic connections and functional organization in Aplysia buccal ganglia. J Neurobiol 10:13-29.

Fournié-Zaluski MC, Soleilhac JM, Turcaud S, Laï-Kuen R, Crine P, Beaumont A, Roques BP (1992) Development of [ $\left.{ }^{125} \mathrm{I}\right] \mathrm{RB} 104$, a potent inhibitor of neutral endopeptidase 24.11, and its use in detecting nanogram quantities of the enzyme by "inhibitor gel electrophoresis." Proc Natl Acad Sci USA 89:6388-6392.

Gardner D (1971) Bilateral symmetry and interneuronal organization in the buccal ganglia of Aplysia. Science 173:550-553.

Goldberg DJ, Ambron RT (1986) Consequences of partial axotomy for production of neurotransmitter vesicles and routing of rapidly transported membrane glycoproteins in the axonal tree. J Neurosci 6:1712-1718.

Gros C, Souque A, Schwartz JC, Duchier J, Cournot A, Baumer P, Lecomte JM (1989) Protection of atrial natriuretic factor against degradation: diuretic and natriuretic responses after in vivo inhibition of enkephalinase (EC 3.4.24.11). Proc Natl Acad Sci USA 86:7580-7584.

Gros C, Souque A, Schwartz JC (1990) Inactivation of atrial natriuretic factor in mice in vivo: crucial role of enkephalinase (EC 3.4.24.11). Eur J Pharmacol 179:45-56.

Hangauer DG, Monzigo AF, Matthews BW (1984) An interactive computer graphics study of thermolysin-catalysed peptide cleavage and inhibition by $N$-carboxymethyl dipeptides. Biochemistry 23:5730-5741.

Holmes MA, Matthews BW (1982) Structure of thermolysin refined at 1.6 A resolution. J Mol Biol 160:623-639.

Johnson AR, Coalson JJ, Ashton J, Larumbide M, Erdos EG (1985) Neutral endopeptidase in serum samples of patients with adult respiratory distress syndrome. Comparison with angiotensin-converting enzyme. Am Rev Respir Dis 132:1262-1267.

Kandel ER (1979) Behavioral biology of Aplysia. San Francisco: W. H. Freeman.

Kenny AJ (1993) Endopeptidase-24.11: putative substrate and possible roles. Biochem Soc Trans 21:663-668.

Kenny AJ, Maroux S (1982) Topology of microvillar membrane hydrolases of kidney and intestine. Physiol Rev 62:91-128.

Kenny AJ, Stephenson SL, Turner AJ (1987) Cell surface peptidases. In: Mammalian ectoenzymes (Kenny AJ, Turner AJ, eds), pp 169-210. London: Elsevier Science Publishers.

Kim YA, Shriver B, Quay T, Hersh LB (1992) Analysis of the importance of arginine 102 in neutral endopeptidase (enkephalinase) catalysis. J Biol Chem 267:12330-12335.

Kreiner T, Kirk MD, Scheller RH (1987) Cellular and synaptic morphology of a feeding motor circuit in Aplysia. J Comp Neurol 264:311-325.

Kupfermann I (1974) Feeding behavior in Aplysia: a simple system for the study of motivation. Behav Biol 10:1-26.

Kyte J, Doolittle RF (1982) A simple method for displaying the hydropathic character of a protein. J Mol Biol 157:105-132.

Lee S, Zambas E, Marsh WL, Redman CM (1991) Molecular cloning and primary structure of Kell blood group protein. Proc Natl Acad Sci USA 88:6353-6357.

Le Moual H, Devault A, Roques BP, Crine P, Boileau G (1991) Identification of glutamic acid 646 as a zinc-coordinating residue in endopeptidase-24.11. J Biol Chem 266:15670-15674.

Le Moual H, Roques BP, Crine P, Boileau G (1993) Substitution of potential metal-coordinating amino acid residues in the zinc-binding site of endopeptidase 24.11. FEBS Lett 324:196-200.

Le Moual H, Dion N, Roques BP, Crine P, Boileau G (1994) Asp650 is crucial for catalytic activity of neutral endopeptidase 24.11. Eur J Biochem 221:475-480.

Lloyd PE (1988) Fast axonal transport of modulatory neuropeptides from central ganglia to components of the feeding system in Aplysia. J Neurosci 8:3507-3514. 
Lloyd PE, Frankfurt M, Stevens P, Kupfermann I, Weiss KR (1987) Biochemical and immunocytological localization of the neuropeptides FMRFamide, SCPA, SCPB, to neurons involved in the regulation of feeding in Aplysia. J Neurosci 7:1123-1132.

Marie-Claire C, Ruffet E, Antonczak S, Beaumont A, O'Donohue M, Roques BP, Fournié-Zaluski MC (1997) Evidence by site-directed mutagenesis that arginine 203 of thermolysin and arginine 717 of neprilysin (neutral endopeptidase) play equivalent critical roles in substrate hydrolysis and inhibitor binding. Biochemistry 36:13938-13945.

Maroux S (1987) Structural and topological aspects. In: Mammalian ectoenzymes (Kenny AJ, Turner AJ, eds), pp 15-45. London: Elsevier Science Publishers.

Martin KC, Casadio A, Huixiang Z, Yaping E, Rose JC, Chen M, Bailey CH, Kandel ER (1997) Synapse specific long-term facilitation of Aplysia sensory to motor synapses: a function for local protein synthesis in memory storage. Cell 91:927-938.

Martins MA, Shore SA, Gerard NP, Gerard C, Drazen JM (1990) Peptidase modulation of the pulmonary effects of tachykinins in tracheal superfused guinea pig lungs. J Clin Invest 85:170-176.

McKelvy JF, Blumberg S (1986) Inactivation and metabolism of neuropeptides. Annu Rev Neurosci 9:415-434.

Miller MW, Alevizos A, Cropper EC, Kupfermann I, Weiss KR (1992) Distribution of buccalin-like immunoreactivity in the central nervous system and peripheral tissues of Aplysia californica. J Comp Neurol 320:182-195.

Miller MW, Beuchausen S, Cropper EC, Eisenger K, Stamm S, Vilim FS, Vitek A, Zajc A, Kupfermann I, Brosius J, Weiss KR (1993a) The buccalin-related neuropeptides: isolation and characterization of an Aplysia cDNA clone encoding a family of peptides cotransmitters. J Neurosci 13:3346-3357.

Miller MW, Beuchausen S, Vitek A, Stamm S, Kupfermann I, Brosius J, Weiss KR (1993b) The myomodulin-related neuropeptides: characterization of a gene encoding a family of peptides cotransmitters in Aplysia. J Neurosci 13:3358-3367.

Miller MW, Rosen SC, Schissel SL, Cropper EC, Kupfermann I, Weiss WR (1994) A population of SCP-containing neurons in the buccal ganglion of Aplysia are radula mechanoafferents and receive excitation of central origin (1994). J Neurosci 14:7008-7023.

Owens DF, Menon JG, Rothman BS (1992) Structure-activity relationship of neurotransmitter alpha-bag cell peptide on Aplysia LUQ neurons: implications regarding its inactivation in the extracellular space. J Neurobiol 23:656-670.

Panoskaltsis-Mortari A, Bucy RP (1995) In situ hybridization with digoxigenin-labeled RNA probes: facts and artifacts. Biotechniques 18:300-307.

Roderick SL, Fournié-Zaluski MC, Roques BP, Matthews BW (1989) Thiorphan and retro-thiorphan display equivalent interactions when bound to crystalline thermolysin. Biochemistry 28:1493-1497.

Roques BP, Fournié-Zaluski MC, Soroca E, Lecomte JM, Malfroy B, Llorens C, Schwartz JC (1980) The enkephalinase inhibitor thiorphan shows antinociceptive activity in mice. Nature 288:286-288.

Roques BP, Noble F, Daugé V, Fournié-Zaluski MC, Beaumont A (1993) Neutral endopeptidase 24.11: structure, inhibition, and experimental and clinical pharmacology. Pharmacol Rev 45:87-146.

Rothman BS, Mayeri E, Scheller RH (1985) The bag cell neurons of Aplysia as a possible peptidergic multitransmitter system: from genes to behavior. In: Gene expression in brain (Zomzely-Neurath C, Walker WA, eds), pp 235-274. New York: Wiley.

Rothman BS, Dekruyff S, Talebian M, Menon JG, Squire CR, Yeh CH, Lee TD (1992) Aplysia peptide neurotransmitters beta-bag cell peptide, Phe-Met-Arg-Phe-amide, and small cardioexcitatory peptide B are rapidly degraded by a leucine amino-like activity in hemolymph. J Biol Chem 267:25135-25140.

Ruchon AF, Marcinkiewicz M, Siegfried G, Tenenhouse HS, Desgroseillers L, Crine P, Boileau G (1998) PEX mRNA is localized in developing mouse osteoblasts and odontoblasts. J Histochem Cytochem 48:459-468.

Saitou N, Nei M (1987) The neighbor-joining method: a new method for reconstructing phylogenetic trees. Mol Biol Evol 4:406-425.

Saleh TM, Kombian SB, Zidichouski JA, Pittman QJ (1996) Peptidergic modulation of synaptic transmission in the parabrachial nucleus in vitro: importance of degradative enzymes in regulating synaptic efficacy. J Neurosci 16:6046-6055.
Sanger F, Nicklen S, Coulson AR (1977) DNA sequencing with chainterminating inhibitors. Proc Natl Acad Sci USA 74:5463-5467.

Seymour AA, Abboa-Offei BE, Smith PL, Mathers PD, Asaad MM, Rogers WL (1995) Potentiation of natriuretic peptides by neutral endopeptidase inhibitors. Clin Exp Pharmacol Physiol 22:63-69.

Shipp MA, Stephano GB, D'Adamio L, Switzer SN, Howard FD, Sinisterra J, Scharrer B, Reinhertz EL (1990) Downregulation of enkephalin-mediated inflammatory responses by CD10/neutral endopeptidase 24.11. Nature 347:394-396.

Shipp MA, Stephano GB, Switzer SN, Griffin JD, Reinhertz EL (1991) CD10 (CALLA)/neutral endopeptidase 24.11 modulates inflammatory peptide-induced changes in neutrophil morphology, migration, and adhesion proteins and is itself regulated by neutrophil activation. Blood 78:1834-1841.

Soleilhac JM, Lafuma C, Porcher JM, Auburtin G, Roques BP (1996) Characterization of a soluble form of neutral endopeptidase-24.11 (EC 3.4.24.11) in human serum: enhancement of its activity in serum of underground miners exposed to coal dust particles. Eur J Clin Invest 26:1011-1017.

Sossin WS, Kirk MD, Scheller RH (1987) Peptidergic modulation of neuronal circuitry controlling feeding in Aplysia. J Neurosci 7:671-681.

Squire CR, Talebian M, Menon JG, Dekruyff S, Lee TD, Shively JE, Rothman BS (1991) Leucine aminopeptidase-like activity in Aplysia hemolymph rapidly degrades biologically active alpha-bag cell peptide fragments. J Biol Chem 266:22355-22363.

Steward O (1997) mRNA localization in neurons: a multipurpose mechanism? Neuron 18:9-12.

Tam LT, Engelbrecht S, Talent JM, Gracy RW, Erdos EG (1985) The importance of disulfide bridges in human endopeptidase (enkephalinase) after proteolytic cleavage. Biochem Biophys Res Commun 133:1187-1198.

The HYP consortium (1995) A gene (PEX) with homologies to endopeptidases is mutated in patients with $\mathrm{X}$-linked hypophosphatemic rickets. Nat Genet 11:130-135.

Thompson EB, Schwartz JH, Kandel ER (1976) A radioautographic analysis in the light and electron microscope of identified Aplysia neurons and their processes after intrasomatic injection of L- $\left({ }^{3} \mathrm{H}\right)$ fucose. Brain Res 112:251-281.

Thompson JD, Higgins DG, Gibson TJ (1994) CLUSTAL W: improving the sensitivity of progressive multiple sequence alignment through sequence weighting, position-specific gap penalties and weight matrix choice. Nucleic Acids Res 22:4673-4680.

Thompson JS, Morice AH (1996) Neutral endopeptidase inhibitors and the pulmonary circulation. Gen Pharmacol 27:581-585.

Turner AJ (1986) Processing and metabolism of neuropeptides. Essays Biochem 22:69-119.

Turner AJ, Murphy LJ (1996) Molecular pharmacology of endothelin converting enzymes. Biochem Pharmacol 51:91-102.

Turner AJ, Tanzawa K (1997) Mammalian membrane metallopeptidases: NEP, ECE, KELL, and PEX. FASEB J 11:355-364.

Turner AJ, Hooper NM, Kenny AJ (1987) Metabolism of neuropeptides. In: Mammalian ectoenzymes (Kenny AJ, Turner AJ, eds), pp 211-248. London: Elsevier Science Publishers.

Van Minnen J (1994) RNA in the axonal domain: a new dimension in neuronal functioning? Histochem J 26:377-391.

Vijayaraghavan J, Scicli AG, Carretero OA, Slaughter C, Moomaw C, Hersh LB (1990) The hydrolysis of endothelins by neutral endopeptidase 24.11 (enkephalinase). J Biol Chem 265:14150-14155.

Weaver LH, Kester WR, Matthews BW (1977) A crystallographic study of the complex of phosphoramidon with thermolysin. A model for the presumed catalytic transition state and for the binding of extended substances. J Mol Biol 114:119-132.

Webb DJ, Monge JC, Rabelink TJ, Yanagisawa M (1997) Endothelin: new discoveries and rapid progress in the clinic. Trends Pharmacol Sci 19:5-8.

Weiss KR, Chiel HJ, Koch U, Kupfermann I (1986) Activity of an identified histaminergic neuron, and its possible role in arousal of feeding behavior in semi-intact Aplysia. J Neurosci 6:2403-2415.

Wickham L, DesGroseillers L (1991) A bradykinin-like neuropeptide precursor gene is expressed in neuron L5 of Aplysia californica. DNA Cell Biol 10:249-258.

Wilhelm JE, Vale RD (1993) RNA on the move: the mRNA localization pathway. J Cell Biol 2:269-274. 